\title{
Expeditious Asymmetric Synthesis of Polypropionates Relying on Sulfur Dioxide-Induced C-C Bond Forming Reactions
}

\author{
Pierre Vogel ${ }^{1, *}$ and José Angel Sordo Gonzalo ${ }^{2}$ \\ 1 Basic Sciences Faculty, Swiss Institute of Technology in Lausanne (EPFL), 1015 Lausanne, Switzerland \\ 2 Departamento de Química Física y Analítica, Facutad de Química, Universidad de Oviedo, \\ 33006 Oviedo, Spain; jasg@uniovi.es \\ * Correspondence: pierre.vogel@epfl.ch
}

Citation: Vogel, P.; Sordo Gonzalo, J.A. Expeditious Asymmetric Synthesis of Polypropionates Relying on Sulfur Dioxide-Induced C-C Bond Forming Reactions. Catalysts 2021, 11, 1267. https://doi.org/10.3390/ catal11111267

Academic Editor: Atsushi Ohtaka

Received: 1 October 2021

Accepted: 19 October 2021

Published: 21 October 202

Publisher's Note: MDPI stays neutral with regard to jurisdictional claims in published maps and institutional affiliations.

Copyright: (c) 2021 by the authors. Licensee MDPI, Basel, Switzerland. This article is an open access article distributed under the terms and conditions of the Creative Commons Attribution (CC BY) license (https:/ / creativecommons.org/licenses/by/ $4.0 /)$.
Abstract: For a long time, the organic chemistry of sulfur dioxide $\left(\mathrm{SO}_{2}\right)$ consisted of sulfinates that react with carbon electrophiles to generate sulfones. With alkenes and other unsaturated compounds, $\mathrm{SO}_{2}$ generates polymeric materials such as polysulfones. More recently, $\mathrm{H}$-ene, sila-ene and heteroDiels-Alder reactions of $\mathrm{SO}_{2}$ have been realized under conditions that avoid polymer formation. Sultines resulting from the hetero-Diels-Alder reactions of conjugated dienes and $\mathrm{SO}_{2}$ are formed more rapidly than the corresponding more stable sulfolenes resulting from the cheletropic additions. In the presence of a protic or Lewis acid catalyst, the sultines derived from 1-alkoxydienes are ionized into zwitterionic intermediates bearing 1-alkoxyallylic cation moieties which react with electro-rich alkenes such as enol silyl ethers and allylsilanes with high stereoselectivity. (C-C-bond formation through Umpolung induced by $\mathrm{SO}_{2}$ ). This produces silyl sulfinates that react with carbon electrophiles to give sulfones (one-pot four component asymmetric synthesis of sulfones), or with $\mathrm{Cl}_{2}$, generating the corresponding sulfonamides that can be reacted in situ with primary and secondary amines (one-pot four component asymmetric synthesis of sulfonamides). Alternatively, Pd-catalyzed desulfinylation generates enantiomerically pure polypropionate stereotriads in one-pot operations. The chirons so obtained are flanked by an ethyl ketone moiety on one side and by a prop-1-en-1-yl carboxylate group on the other. They are ready for two-directional chain elongations, realizing expeditious synthesis of long-chain polypropionates and polyketides. The stereotriads have also been converted into simpler polypropionates such as the cyclohexanone moiety of baconipyrone $A$ and B, Kishi's stereoheptad unit of rifamycin S, Nicolaou's $C_{1}-C_{11}$-fragment and Koert's $C_{16}-C_{I}$ fragment of apoptolidin A. This has also permitted the first total synthesis of (-)-dolabriferol.

Keywords: aldol reactions; alkoxyallylic cation intermediates; apoptolidin A; baconipyrones; dolabriferol; hetero-Diels-Alder reactions; long-chain polyketides; retro-ene reaction; rifamycin S; Umpolung with $\mathrm{SO}_{2}$

\section{Introduction}

Natural polypropionates are a large subgroup of polyketides (1,3-polyols) constructed by $\mathrm{C}_{3}$-units. They are found in marine organisms including mollusks, sponges, fungi and actinomycetes [1-5], while some of them are also isolated from terrestrial resources [6]. Polypropionates interspace methyl groups in the polyketide chain which arise biochemically directly from the propionate unit or from the acetate-methionine motif [7-9]. They are characterized by abundant structural diversities and are important building blocks in the biosynthesis of several kinds of antibiotics such as macrolides, polyethers and cyclic peptides [10]. Most of them exhibit various kinds of bioactivities, especially antitumor and antimicrobial effects [11]. Examples of natural products containing polypropionate fragments are collected in Figure 1. 
<smiles>[R]Cc1oc([C@@H](C)C(=O)[C@H](C)[C@@H](O)[C@@H](C)C(=O)O[C@@H]2[C@H](C)[C@](O)(CC)[C@@H](C)C(=O)[C@@H]2C)c(C)c(=O)c1C</smiles>

1: baconipyrone $\mathrm{A}, \mathrm{R}=\mathrm{Me}$

2: baconipyrone $\mathrm{B}, \mathrm{R}=\mathrm{H}$

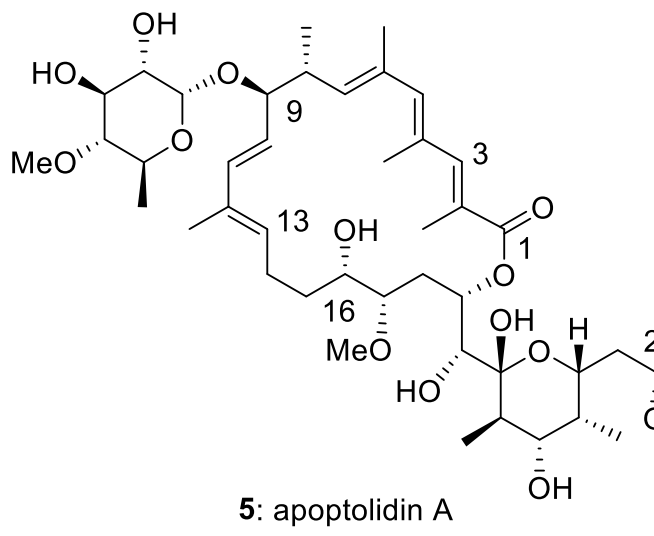

5: apoptolidin A<smiles>CCC(=O)[C@H](C)[C@@H](O)[C@@H](C)C(=O)O[C@H]1[C@@H](C)[C@H](C(C)C)O[C@](O)(CC)[C@H]1C</smiles>

3: (-)-dolabriferol

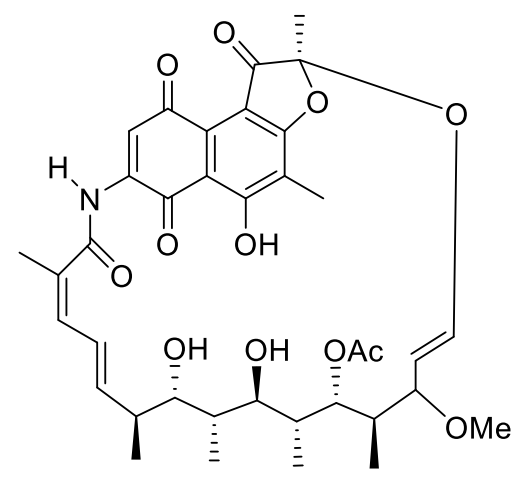

4: rifamycin S

Figure 1. Examples of natural products containing polypropionate fragments, their synthesis being presented in this report.

The stereoselective construction of polypropionates is challenging, mainly because of stereochemical issues. Aldol reactions, crotylations, allenylation and propargylation of aldehydes $\mathrm{R}^{1} \mathrm{CHO}$ have been used extensively to construct the four possible stereoisomeric $\mathrm{R}^{1} \mathrm{CH}(\mathrm{OH})-\mathrm{CH}(\mathrm{Me})-\mathrm{R}^{2}$ units [12-19]. More recently, the same fragments have been prepared through the transition metal catalyzed enantioselective hydro(hydroxycarbation) of terminal alkene $\mathrm{R}^{2} \mathrm{CH}=\mathrm{CH}_{2}$ with alcohols $\mathrm{R}^{1} \mathrm{CH}_{2} \mathrm{OH}$ or aldehydes $\mathrm{R}^{1} \mathrm{CHO}+\mathrm{H}_{2}$ [20]. The latter methods developed by Krische and co-workers have permitted significant shortening of the total syntheses of many natural polyketides and polypropionates [21-28]. The stereoselective construction of all possible stereoisomers of stereotriads $\mathrm{R}^{3} \mathrm{CH}(\mathrm{Me})$ $\mathrm{CH}(\mathrm{OH})-\mathrm{CH}(\mathrm{Me})-\mathrm{R}^{4}$ (6, Figure 2) has been achieved by many methods [29] including those based on aldol or crotylation reactions of an aldehyde or its metallic enolate analogue bearing an $\alpha$-methyl substituent [30-36].<smiles>[R]C(C)C(O)C([R])C</smiles>

6: 1,2-syn 2,3-syn<smiles>[R]C(C)[C@H](O)[C@@H]([R])C</smiles>

1,2-anti 2,3-syn<smiles>[R]C(C)[C@H](O)[C@@H]([R])C</smiles>

1,2-anti

2,3-anti<smiles>[R]C(C)C(O)C([R])C</smiles>

1,2-syn

2,3-anti

Figure 2. Four possible diastereomeric polypropionate stereotriads of type $\mathrm{R}^{3}-\mathrm{CH}(\mathrm{Me})-\mathrm{CH}(\mathrm{OH})$ $\mathrm{CH}(\mathrm{Me})-\mathrm{R}^{4}$. Their enantiomers are not shown. Other stereotriads could be of the type $\mathrm{R}^{3}-\mathrm{CH}(\mathrm{OH})-$ $\mathrm{CH}(\mathrm{Me})-\mathrm{CH}(\mathrm{OH})-\mathrm{R}^{4}$.

Non-aldol formation of stereotriads has been proposed, such as the Sharpless asymmetric epoxidation of allyl alcohol followed by Pd-catalyzed hydrogenolysis of alkenyl oxirane with $\mathrm{HCOOH}[37,38]$ and the cuprate addition to epoxides [39-41]. A method applying an intramolecular Rh-catalyzed silylformylation/crotylsilylation/ "aprotic" Tamao oxidation sequence has been developed by Leighton and co-workers [42-44]. Stereotriads 
have been prepared through double oxidative hydroboration of allenyl alcohols [45]. Carreira and co-workers used enantiomerically pure chiral nitrile oxides and allylic alcohols to generate enantiomerically pure isoxazolines [46,47]. This permitted the preparation of all four possible dipropionates diastereoisomers, in a protected form, starting with the same set of reagents. Erythronolide A has been obtained by this method [48]. The Diels-Alder additions of alkenes to 1,3-dienes produce cyclohexenes containing up to four stereocenters. Danishefsky and co-workers have generated polypropionates via the Diels-Alder reaction. Cycloadditions of aldehydes to 1-methoxy-2-methyl-3-silyloxypenta-1,3-diene produce pyrans, a molecular fragment in many polypropionates $[49,50]$. The Diels-Alder reaction between 2,4-dimethylfuran and enantiomerically pure 1-cyanovinyl carboxylates produces enantiomerically pure 2-cyano-1,5-dimethyl-7-oxabicyclo[2.2.1]hept-5-en-2-yl esters. The alkaline hydrolysis of the latter liberates the chiral auxiliary (a carboxylic acid) which can be recycled. The bicyclic compounds so obtained permitted Vogel and co-workers to prepare several stereotetrads [51,52]. Alternatively, Plumet and Arjona used a Diels-Alder reaction between furan and acrylic acid which provided, after several transformations, a complete library of all possible stereotetrads [53,54]. Hunt and Grieco obtained polypropionates starting with the opening at the bridgehead of oxabicyclo[3.2.1]octenes employing silyl ketene acetals [55]. On their side, Toste and co-workers applied the enantioselective aminecatalyzed Kornblum-DeLaMare rearrangement, a reaction first described by Hagenbuch and Vogel in 1980 [56], on a 3-benzyloxy-2,4,8-trimethyl-6,7-dioxabicyclo[3.2.2]non-8-ene derivative to generate the two polypropionate fragments of dolabriferol (Figure 1) [57].

\section{One-Pot Synthesis of Polypropionate Stereotriads Ready for Bidirectional Chain Elongations}

For the stereotriads 6 and their enantiomeric forms (Figure 2) to become useful chirons (enantiomericallly pure synthetic intermediates) in the constructions of complicated polypropionates and analogues, their alcoholic moiety must be protected adequately and their $\mathrm{R}^{3}$ et $\mathrm{R}^{4}$ terminus should be functions that can enter directly in stereoselective $\mathrm{C}-\mathrm{C}$ bond forming reactions, typically metal aldol reactions. Chirons of type $\mathbf{7}$ and $\mathbf{8}$ (and their enantiomers) have been obtained in one-pot operations (Scheme 1) [16]. Their group $R^{3}$ is an ethyl ketone which can be elongated into a system containing up to two further stereogenic centers via a direct aldol reaction, while the $\mathrm{R}^{4}$ terminus is a protected ethyl ketone under the form of (Z)-prop-1-en-1-yl carboxylate (ethyl ketone enol carboxylate) that stays intact and can be used in the second chain elongation reaction, also producing up to two further stereogenic centers (see below Section 4).

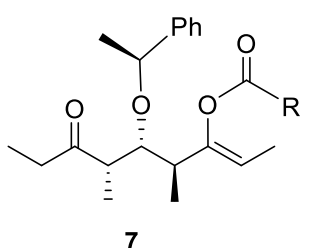<smiles>C/C=C(/CC)OCCO</smiles>

(Z)-9

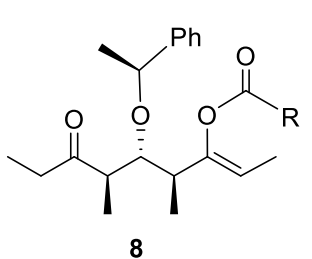

8

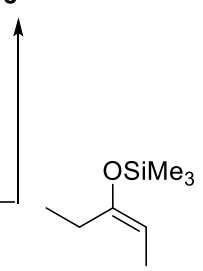

(E)-9

Scheme 1. One-pot synthesis of syn, anti and anti, anti stereotriads 7 and 8 through $C-C$ bond formation between an 1-((1S)-phenylethyloxy)-2-methylpenta-1,3-dien-3-yl carboxylic esters $\mathbf{1 0}$ and the (E)- or (Z)-enoxysilane derived from butan-3-one ((E)-9, (Z)-9). HA is either a protic (e.g., $\left.\left(\mathrm{CF}_{3} \mathrm{SO}_{2}\right)_{2} \mathrm{NH}\right)$ or Lewis acid (e.g,: $\left.\mathrm{Me}_{3} \mathrm{SiOSO}_{2} \mathrm{CF}_{3}\right)$ catalyst. 
The enantiomers of stereotriads 7 and 8 are obtained in the same way using $(R)-1$ phenylethanol instead of (S)-1-phenylethanol to generate dienes 10. Other 1-arylethanols can be used to generate more enantiomerically pure dienes (see below). The $\mathrm{SO}_{2}$ is recovered at the end of the process. With the acid catalyst (e.g., $\left.\mathrm{HA}=\left(\mathrm{CF}_{3} \mathrm{SO}_{2}\right)_{2} \mathrm{NH}\right)$ it induces the Umpolung of the electron-rich diene into an alkoxyallylic cation intermediate (see below Section 3). R can be an alkyl (e.g., $\mathrm{Me}_{2} \mathrm{CH}$ ) or an aryl group (e.g., Ph).

\section{Sulfur Dioxide as Umpolung Agent to Promote Carbon-Carbon Bond Forming Reactions between Alkenes and Dienes}

In the presence of $\mathrm{SO}_{2}$, alkenes, alkynes and polyenes produce polymeric materials, including polysulfones (copolymer with sulfur dioxide) [58-60]. Competing with these reactions, $\mathrm{SO}_{2}$-catalyzed alkene isomerization can be observed. We have demonstrated that the latter reaction may not imply a hetero-ene reaction of the alkene with $\mathrm{SO}_{2}$, followed by a fast [1,3]-sigmatropic shift of the intermediate $\beta, \gamma$-sulfinic acid and retro-ene reaction [61,62]. Instead, an allylic hydrogen atom is abstracted form the alkene by an alkanesulfonyl radical intermediate equilibrating with the polysulfone [63-65]. Since 1914 [66] it has been well-known that 1,3-dienes (that can adopt a s-cis-conformation) and sulfur dioxide equilibrate with their sulfolenes (cheletropic additions). On heating $\left(>100{ }^{\circ} \mathrm{C}\right)$ the sulfolenes undergo cheletropic eliminations giving back the 1,3-dienes and $\mathrm{SO}_{2}$. The first examples of hetero-Diels-Alder additions of $\mathrm{SO}_{2}$ involved highly reactive dienes such as 1,4,5,6-tetramethyl-2,3-dimethylidenetriclo[2.1.1.0 $0^{5,6}$ ]hexane [67] and orthoquinodimethane [68]. Below $-60{ }^{\circ} \mathrm{C}$ simple 1,3-dienes such as isoprene and piperylene react with $\mathrm{SO}_{2}$ equilibrating with their sultines resulting from hetero-Diels-Alder reactions that are much faster than the corresponding cheletropic additions. Deguin and Vogel showed in 1992 that $(E, E)$-deuteriopiperylene (11) equilibrates with sultine 12 at $-80{ }^{\circ} \mathrm{C}$ in the presence of an acid catalyst such as $\mathrm{CF}_{3} \mathrm{COOH}$. At $-60{ }^{\circ} \mathrm{C} 12$ is isomerized into the more stable isomeric sultine $\mathbf{1 3}$, by cycloreversion into the initial cycloaddents and readdition in a second hetero-Diels-Alder reaction (Scheme 2). Both the [4+2]-cycloadditions $\mathbf{1 1}+\mathrm{SO}_{2} \rightarrow \mathbf{1 2}$ and $\mathbf{1 1}+\mathrm{SO}_{2} \rightarrow \mathbf{1 3}$ are highly regio- and stereoselective [69]. As for many Diels-Alder reactions, the acid-catalyzed hetero-Diels-Alder reactions of $\mathrm{SO}_{2}$ adheres to the Alder-endo rule and to the Woodward-Hoffmann rule of suprafaciality for the diene [69]. Sulfur dioxide itself catalyzes its cycloadditions [70-73]. In the absence of acid, the secondary deuterium kinetic isotopic effects of the $\mathrm{SO}_{2}$ reaction with the dideuterodiene $15-\mathrm{d}_{2}$ induced a regioselectivity opposite to the equilibrium isotopic regioselectivity. Sultine ortho-17 formed faster than regioisomer meta-17. On staying at $-55^{\circ} \mathrm{C}$, ortho-17 was slowly isomerized into meta-17 (Scheme 2). This demonstrates that the hetero-Diels-Alder reaction of $\mathrm{SO}_{2}$ follows a mechanism with asynchronous formation of the $\mathrm{C}-\mathrm{S}$ and $\mathrm{C}-\mathrm{O}$ bonds in the transition state: the $\mathrm{C}-\mathrm{S}$ bond is formed to a greater extent than the $\mathrm{C}-\mathrm{O}$ bond [74].

The sulfolenes arising from the cheletropic additions of $\mathrm{SO}_{2}$ to alkyl substituted 1,3-dienes are about $10 \mathrm{kcal} \mathrm{mol}^{-1}$ more stable than their isomeric sultines. In contrast, fluorosultines that result from the hetero-Diels-Alder reactions of $\mathrm{SO}_{2}$ with 1-fluoro-1,3dienes are more stable than their isomeric sulfolenes. This is assigned to an enthalpic anomeric effect of the $\mathrm{F}-\mathrm{C}-\mathrm{O}(\mathrm{S}=\mathrm{O})$ moiety in the sultines [75].

With 1-alkoxy-3-acyloxy-1,3-dienes $\mathbf{1 0}$ (prepared in four steps from butan-3-one and (S)-1-phenylethanol [76], the corresponding sultines 19 are not seen at $-100{ }^{\circ} \mathrm{C}$ (large excess of $\mathrm{SO}_{2}, \mathrm{CH}_{2} \mathrm{Cl}_{2}$ or toluene as co-solvent) as these dienes generate the corresponding sulfolenes at this temperature already. Nevertheless, sultines $\mathbf{1 9}$ are believed to be formed as intermediates before the isomeric sulfolenes (Scheme 3). In the presence of an acid catalyst (protic acid or Lewis acid), they equilibrate with zwitterionic intermediates 20 that can be reacted with electron-rich alkenes such as enoxysilane (Z)-9. This generates the silyl sulfinates 24. The role of $\mathrm{SO}_{2}$ is to convert the electron-rich dienes into 1-alkoxyallyl cation intermediates, realizing an inversion of polarity (Umpolung) that make possible the $C-C$ coupling reaction between the two nucleophilic partners 10 and (Z)-9 [77]. 


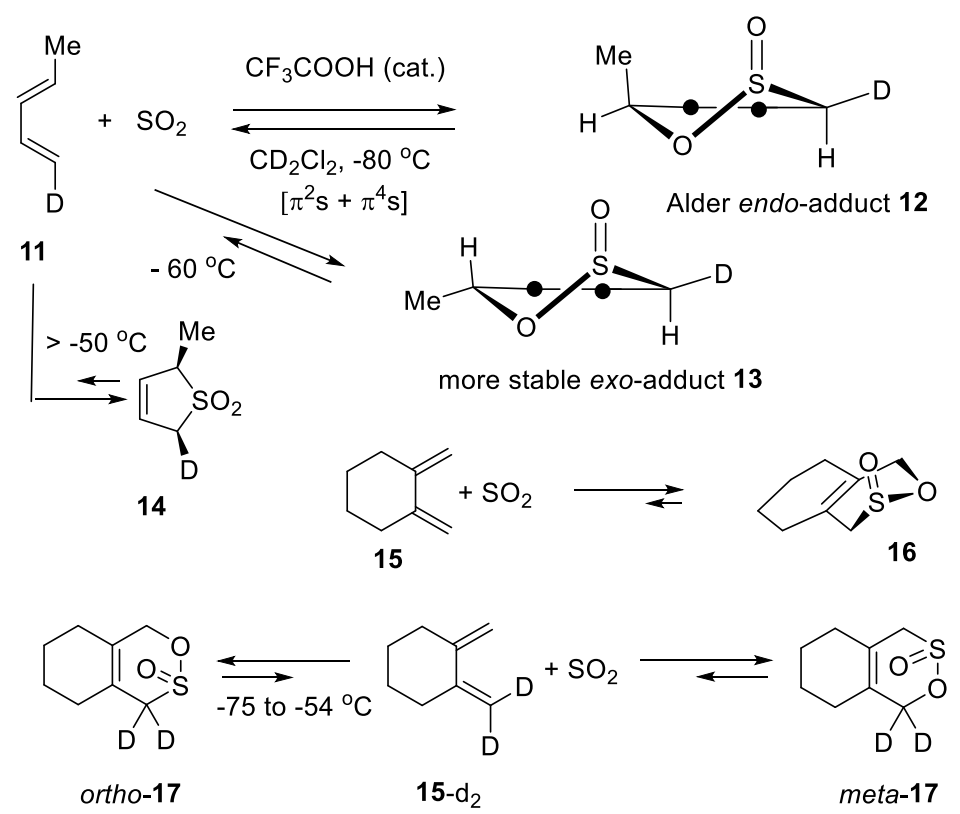

favored kinetically

favored thermodynamically

Scheme 2. Simple dienes that can adopt a s-cis conformation undergo $\mathrm{SO}_{2}$ and acid-catalyzed heteroDiels-Alder reactions with $\mathrm{SO}_{2}$ at low temperature, giving sultines that are about $10 \mathrm{kcal} \mathrm{mol}^{-1}$ less stable than the corresponding sulfolenes.

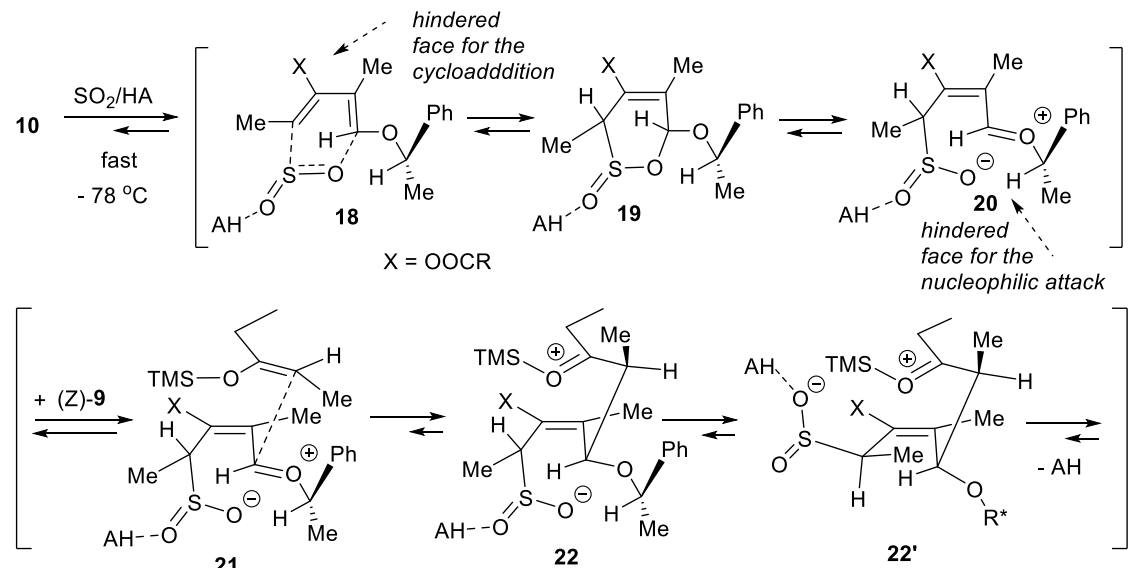

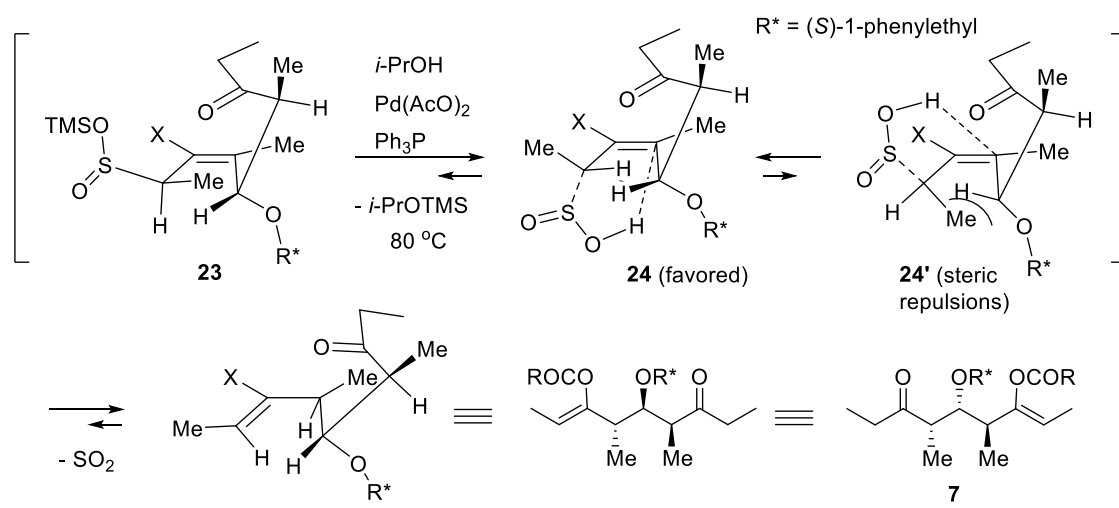

Scheme 3. Proposed mechanism for the reaction cascade producing the syn, anti-stereotriad 7 as major product: (1) face-selective acid-catalyzed hetero-Diels-Alder reaction of $\mathrm{SO}_{2}$, (2) immediate ionization of the sultine so-obtained into a zwitterion, (3) face-selective quenching of the alkoxyallyl cation intermediate by the enoxysilane, (4) intramolecular or intermolecular silyl transfer forming a silyl sulfinate (can be isolated), (5) its Pd-catalyzed alcoholysis with isopropanol forming the corresponding, $\beta, \gamma$-unsaturated sulfinic acid which (6) undergoes a face-selective $\mathrm{H}$-retro-ene reaction. 
After removal of $\mathrm{SO}_{2}$ in excess and solvent under vacuum, enough $\mathrm{K}_{2} \mathrm{CO}_{3}$ in $\mathrm{CH}_{3} \mathrm{CN}$ was added to neutralize the acid catalyst. Then a 1:1 mixture of $\mathrm{Pd}(\mathrm{AcO})_{2} / \mathrm{Ph}_{3} \mathrm{P}$ and isopropanol was added, and heating to $80{ }^{\circ} \mathrm{C}$ produced the final stereotriads. The stereoselectivity of the reaction cascade is explained in the following way (Scheme 3). The hetero-Diels-Alder reaction of $\mathrm{SO}_{2}$ is face selective because the chiral auxiliary (1-alkoxy substituent of the diene) favors transition structure 18, the least encumbered face of the diene reacting preferentially. The acid catalyzed ionization of the resulting sultines $\mathbf{1 9}$ generate ion-pairs $\mathbf{2 0}$ in which the sulfinate anion remains closed to the 1-alkoxyallyl cation moieties. This forces the nucleophile (e.g., enoxysilane (Z)-12) to attack 20 on the face opposite to that occupied by the sulfinate anion (transition structure 21). The resulting adducts 22 undergo intramolecular silyl group transfers via conformations $22^{\prime}$. Alternatively, two molecules of $\mathbf{2 2}$ could undergo a double intramolecular silyl group transfer giving the silyl sulfinates $\mathbf{2 3}$. Alcoholysis of $\mathbf{2 3}$ gives sulfinic acids $\mathbf{2 4}$ which undergo H-retro-ene reactions generating 7 , the stereoselectivity of which is controlled by steric factors making transition structures 24 preferred to $24^{\prime}$. For the reaction cascade using enoxysilane ( $\mathrm{Z})-\mathbf{9}$ and diene 10 with $\mathrm{R}=i$-Pr, $\mathrm{R}^{*}=(S)-1$-phenylethyl $)\left(1: 1 \mathrm{SO}_{2} /\right.$ toluene, catalyst $\left.\mathrm{AH}=\left(\mathrm{CF}_{3} \mathrm{SO}_{2}\right)_{2} \mathrm{NH}\right)$ the corresponding stereotriads 7 and 8 were isolated in 67 and 13 $\%$ yield, respectively, after column chromatography. Using Greene's chiral auxiliaries ((S)1-[2,4,6- tris(isopropyl)phenyl]ethanol) [78]) instead of inexpensive (S)-1-phenylethanol the diastereoselectivity syn, anti vs. anti,anti-stereotriad was better than 95:5 [79].

The silyl sulfinates $\mathbf{2 3}$ can be isolated, or converted in situ into sulfinate salts that are quenched by all kinds of electrophiles to give sulfones (four-component synthesis of polyfunctional sulfones [80]), or converted in situ (with $\mathrm{Cl}_{2}$ or $\mathrm{N}$-chlorosuccinimide) into sulfonyl chlorides that react with amines to produce sulfonamides (four-component synthesis of polyfunctional sulfonamides [81,82]). Acidic treatment of $\mathbf{2 3}$ also leads to desulfinylation producing the stereotriads in a lower yield, due to elimination of 1-phenylethanolgenerating dienes $\mathbf{2 6}$ and aldols 27, the latter undergoing retro-aldol decomposition into penta-3-one and aldehydes $\mathbf{2 8}$ (Scheme 4). This is avoided when the silyl sulfinates are treated under neutral or slightly basic conditions $\left(\mathrm{K}_{2} \mathrm{CO}_{3}\right)$ in isopropanol in the presence of a catalytic amount of $\mathrm{Pd}(\mathrm{AcO})_{2}$ and $\mathrm{Ph}_{3} \mathrm{P}$. Without $\mathrm{Ph}_{3} \mathrm{P}$ the reaction does not occur (formation of $\mathrm{Pd}^{(0)}$ species as catalyst). One can envisage a $\mathrm{Pd}^{(0)}$ complex intermediate which adds oxidatively (retention of configuration) into the allylic $\mathrm{C}-\mathrm{SO}_{2} \mathrm{SiMe}_{3}$ bond of 23 . Subsequent desulfinylation and protolysis of the $\mathrm{Pd}-\mathrm{SiMe}_{3}$ bond gives $i-\mathrm{PrOSiMe}_{3}$ (driving force) and an (allyl)palladium hydride that undergoes regioselective and stereoselective $\beta$-insertion of hydride into another (allyl)Pd intermediate. An alternative mechanism (Scheme 3) is to invoke that the $\mathrm{Pd}^{(0)}$ role is just to promote the Si-sulfinate bond cleavage under non-acidic conditions generating the corresponding $\beta, \gamma$-unsaturated sulfinic acids that, in turn, undergo H-retro-ene elimination of $\mathrm{SO}_{2}$ [83].

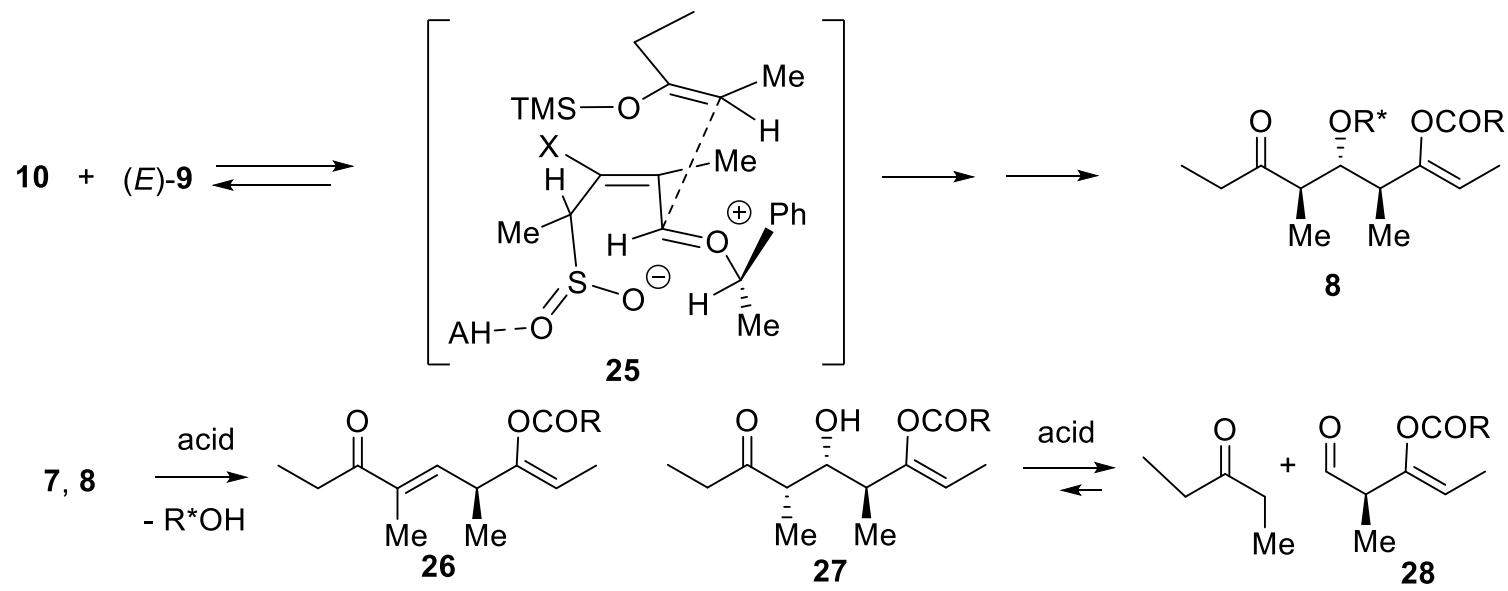

Scheme 4. Mechanism for the preparation of the anti,anti-stereotriad 8 and formation of co-products under acidinduced desulfinylation. 


\section{Long-Chain Polypropionates through Bidirectional Chain Elongation}

The polypropionate 31 (a stereodecad) containing 10 contiguous stereogenic centers has been obtained by two successive metal-aldol reactions of stereotriad 7 (Scheme 5) [84]. Applying Paterson's method for direct formation of enoxyboranes [85-87] the dicyclohexyl(enoxy)borane derived from 7 reacted with acetaldehyde giving an boron anti-2methylaldolate that was reduced directly with $\mathrm{NaBH}_{4}$ generating a anti,anti-2-methyl1,3-diol moiety, which was protected as the acetonide 29 (a stereohexad in one pot operation) in $61 \%$ overall yield. The (Z)-enol isobutyrate group of 29 was converted with retention into the $(Z)$ lithium enolate 30 by reaction with $\mathrm{MeLi} \cdot \mathrm{LiBr}$ in ether. The latter added to the acetonide of D-glyceraldehyde giving a major lithium aldolate. Its phenylethyl ether was hydrogenolyzed under standard conditions and the aldol was reduced with $\mathrm{Me}_{4} \mathrm{NB}(\mathrm{AcO})_{3} \mathrm{H}[88,89]$ selectively into the corresponding anti-1,3-diol 31 (67\% overall yield).

\section{1. (c-Hex $)_{2} \mathrm{BCl}, \mathrm{Et}_{3} \mathrm{~N}, 15^{\circ} \mathrm{C}$}<smiles>[R]O[C@H](C(C)/C([X])=C\C)[C@@H](C)C(=O)CC</smiles>

2. $\mathrm{MeCHO},-78^{\circ} \mathrm{C}$

3. $\mathrm{NaBH}_{4}, \mathrm{MeOH},-78^{\circ} \mathrm{C}$

4. $\mathrm{H}_{2} \mathrm{O}_{2}, \mathrm{NaHCO}_{3}, \mathrm{MeOH},-5^{\circ} \mathrm{C}$

5. $(\mathrm{MeO})_{2} \mathrm{CMe}_{2}, \mathrm{TsOH}$

$7\left(R^{*}=(S)\right.$-1-phenylethyl, $X=$ isobutyrate $)$<smiles>[R]OC(C(C)C(C)C([X])=CC)[C@H]1OC(C)(C)OC(C)[C@@H]1C</smiles><smiles>C/C=C(/O)[C@@H](C)[C@@H](O[Ga])[C@H](C)[C@H]1OC(C)(C)O[C@@H](C)[C@H]1C</smiles>

30
1.<smiles>CC1(C)OCC(C=O)O1</smiles>

2. $\mathrm{H}_{2}, \mathrm{Pd}(\mathrm{OH})_{2} / \mathrm{C}, \mathrm{MeOH}, 25^{\circ} \mathrm{C}$

3. $\mathrm{Me}_{4} \mathrm{NB}(\mathrm{OAc})_{3} \mathrm{H}, \mathrm{AcOH}$, $-20{ }^{\circ} \mathrm{C}, 24 \mathrm{~h}$<smiles>C[C@H]([C@H]1COC(C)(C)O1)[C@@H](O)[C@@H](C)[C@@H](O)[C@H](C)[C@H]1OC(C)(C)O[C@H](C)[C@H]1C</smiles>

31

Scheme 5. An example of bidirectional chain elongation of stereotriad 7 by two successive metal-aldol reactions; synthesis of a stereodecad from a stereotriad requiring the isolation of one synthetic intermediate.

\section{First Total Asymmetric Synthesis of the Cyclohexanol Subunit of Baconipyrones A and $B$}

Baconipyrones A-D were isolated in 1989 by Faulkner and co-workers from Siphonaria baconi [90]. The stereotriad $7\left(\mathrm{R}=i-\mathrm{Pr}, \mathrm{R}^{*}=(S)-1\right.$-phenylethyl) has been converted in two steps into cyclohexanone 34 (overall yield: $86 \%$ ), subunit of baconipyrones A and B (Figure 1) [91]. Transesterification of enol isobutyrate 7 (Scheme 6) with $\mathrm{Bu}_{3} \mathrm{SnOMe}[92,93]$ induced the desired stereoselective intramolecular aldol reaction, giving 33. Transition structure 32 was proposed to explain the stereoselectivity hydrogenolysis of 33 and provided 34 quantitatively. 


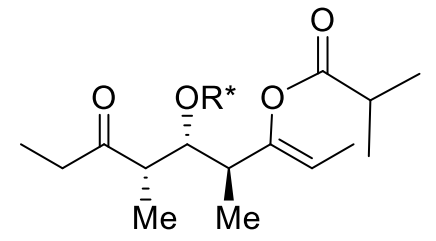

$7\left(R^{*}=(S)-1\right.$-phenylethyl)<smiles>CC[C@]1(O)C(C)[C@H](O)[C@@H](C)C(=O)[C@H]1C</smiles>
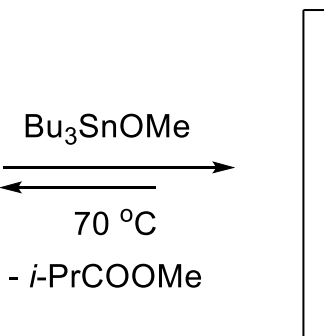

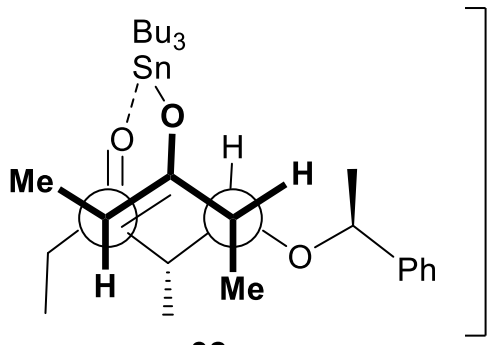

32

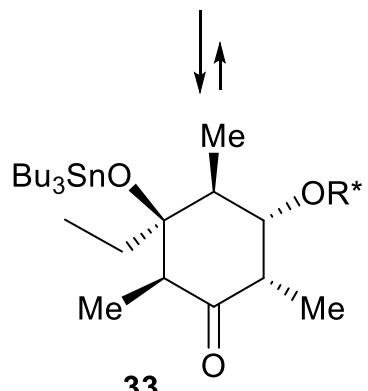

Scheme 6. Synthesis of the cyclohexanone subunit of baconipyrones A and B.

\section{First Total Asymmetric Synthesis of (-)-Dolabriferol}

(-)-Dolabriferol was isolated from Dolabrifera dolabrifera, a shell-less mollusk. (-)- Dolabriferol is assumed to protect the mollusk from predators [94]. This natural product is made of two polypropionates subunits linked by an ester function, a structural motif which is also found in baconipyrones (Figure 1). Ozonolysis of pure 35 arising from the reaction of diene $13\left(\mathrm{R}^{\prime}=(R)-1\right.$-phenylethyl) and enoxysilane $(E)-9$ provided the carboxylic subunit (+)-36 of (-)-dolabriferol (two steps from diene 13). Similarly, reaction of diene 37 with enoxysilane 38 resulted in a stereotriad $39(67 \%$, single diastereomer, diasteroselectivity better than 95:5), that was reduced with stereoselectivity into alcohol 40 (a stereotetrad in two steps from diene 37). Protection as an allyl carbonate (alloc), followed by $\mathrm{TiCl}_{4}$-induced $E_{1}$ cleavage of the 1-phenylethyl ether moiety furnished alcohol 41 . The esterification of 41 with carboxylic acid (+)-36 using Paterson's protocol [95] produced 42 (DMAP = 4-dimethylaminopyridine). Selective removal of the acetyl group was realized by treatment in pure $\mathrm{Bu}_{3} \mathrm{SnOMe}$ at $70{ }^{\circ} \mathrm{C}$, followed by $\mathrm{KF} / \mathrm{H}_{2} \mathrm{O}$ work-up. Subsequent treatment with $\mathrm{CF}_{3} \mathrm{COOH}$ removed the phenylethyl ether, giving 43 . Final deprotection of the alloc group (TPPS $=3,3^{\prime}, 3^{\prime \prime}$-phosphinidynetris(benzenesulfonic acid) trisodium salt) and formation of the cyclic hemiacetal gave (-)-dolabriferol (Scheme 7).[96] Since this first total synthesis which established the absolute configuration of (-)-dolabriferol, several other synthetic approaches have been proposed, sometimes requiring more steps [57,97-100]. 
<smiles>[R9]C=C(C)C1=CC[C-](C)C(=O)O1</smiles><smiles>[Z7]O/C=C(C)/C(=C/C)OC(C)C</smiles>

$37 R^{*}=(S)-1$-phenylethyl

(67\%)

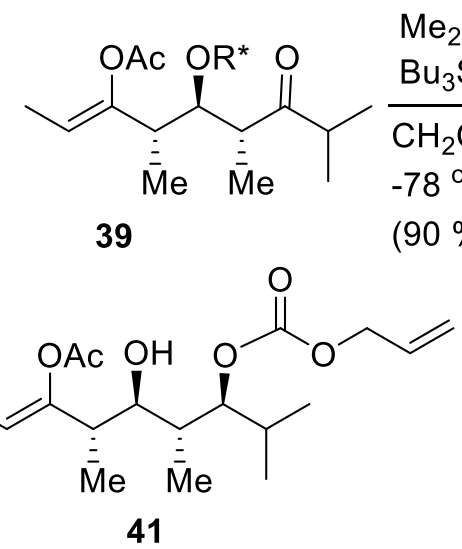

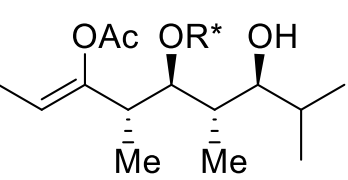

40

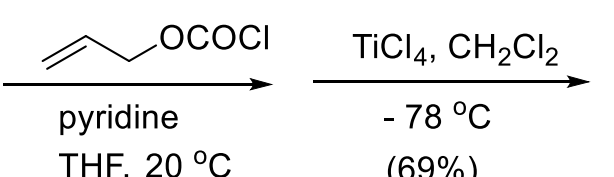

$(91 \%)$

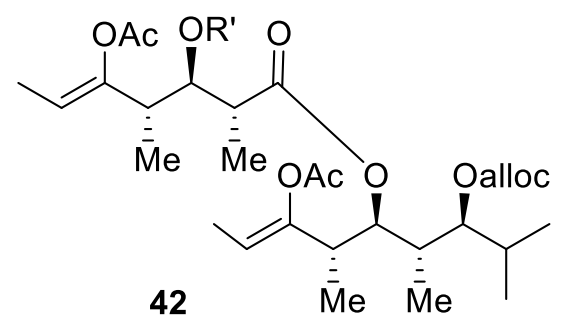

1. $\mathrm{Bu}_{3} \mathrm{SnOMe}$, $70^{\circ} \mathrm{C}, 0.1$ Torr

2. $\mathrm{KF}, \mathrm{H}_{2} \mathrm{O}, 20^{\circ} \mathrm{C}$

3. $\mathrm{CF}_{3} \mathrm{COOH}$; anisole $\mathrm{CH}_{2} \mathrm{Cl}_{2}, 20^{\circ} \mathrm{C}$ (96\%, 3 steps)<smiles>CCC(=O)[C@H](C)[C@@H](O)[C@@H](C)C(=O)O[C@H]1[C@@H](C)[C@H](C(C)C)O[C@](O)(CC)[C@H]1C</smiles>

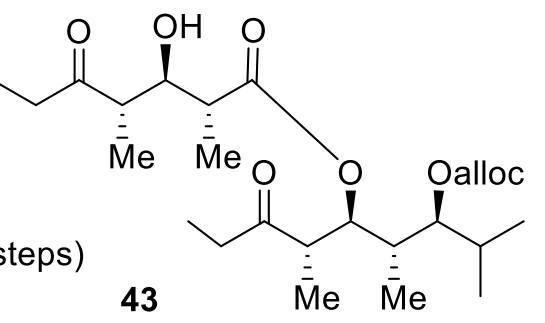

$\mathrm{Pd}(\mathrm{OAc})_{2} / \mathrm{Et}_{2} \mathrm{NH}$

TPPS

$\mathrm{MeCN}, \mathrm{H}_{2} \mathrm{O}, 20^{\circ} \mathrm{C}$

(99\%)

Scheme 7. Total asymmetric synthesis of (-)-dolabriferol.

\section{Expeditious Asymmetric Synthesis of the Stereoheptad $C_{19}-C_{27}$ of Rifamycins: Formal Total Synthesis of Rifamycin $S$}

Rifamycins [101-103] are antibiotics belonging to the group of naphthalenic ansamycins [104] characterized by an aliphatic bridge (polypropionate chain) linking two non-adjacent centers of an aromatic moiety. They are produced from Streptomyces mediterranei [105] and are active against a large variety of organisms, including bacteria, eukaryotes and viruses [106]. Rifamycins have shown also antitumour activity [107] and anti-inflammatory activity [108]. At present, rifamycins and analogues are applied in the treatment of tuberculosis. They inhibit bacterial DNA-dependent RNA polymerase [109-111]. Rifamycin S (4) and several analogues showing promising activities have been prepared [112-115].

The first total synthesis of rifamycin S (4) was reported by Kishi and co-workers in 1980 [116-119]. The stereoheptad (-)-48 is a key intermediate for the construction of the ansa chain. It was obtained in 26 steps and 5.2\% overall yield from (2S)-3-benzyloxy-2methylpropanal. Since then, several total asymmetric syntheses of the polypropionate fragment have been proposed [120-123]. The construction of the $C_{19}-C_{27}$ fragment ((-)-48 
and analogues) of this antibiotic has become a challenging target for the testing of asymmetric synthetic methods and strategies [50,124-141].

Starting from the readily available diene $10\left(R^{*}=(S)-1\right.$-phenylethyl, $X=$ isobutyrate, Scheme 1) Kishi's intermediate (-)-48 was obtained in $25 \%$ yield requiring the isolation of only four synthetic intermediates (Scheme 8). The (Z)-enol ether 44 resulting from the silylation of ethyl ketone 7 (derived from diene 10) reacted with 9-bromo-9borabicyclo[3.3.1]nonane (BrBBN) in $\mathrm{CH}_{2} \mathrm{Cl}_{2}$ (silyl/boron exchange) and then with aldehyde 45 to produce a 12.5:1 mixture of 46 and 9-epimer in $81 \%$ yield. Pure 46 was reduced under Evans' conditions $[88,89]$ to give diol 47 . The next five operations were carried out in the same pot without isolating any intermediate. Treatment of 47 with $\mathrm{AcOH}$ cleaved the silyl ether. Then hydrogenolysis removed the phenylethyl group. The crude tetrol so obtained was converted into the corresponding diacetonide. Ozonolysis of the enol isobutyrate moiety gave a mixed anhydride that was reduced with $\mathrm{LiAlH}_{4}$ into (-)-48 [142].

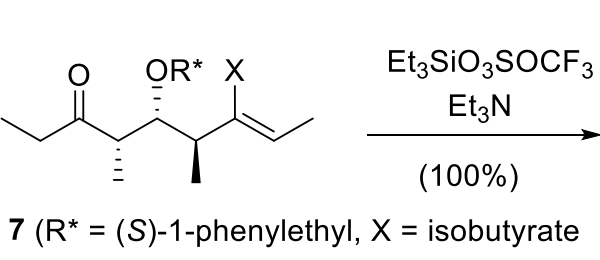

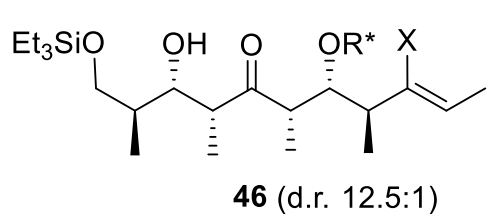

1. $\mathrm{AcOH}$

2. $\mathrm{H}_{2} / \mathrm{Pd}(\mathrm{OH})_{2} / \mathrm{C}$

3. $(\mathrm{MeO})_{2} \mathrm{CMe}_{2}, \mathrm{TsOH}$

(75\%, one-pot)

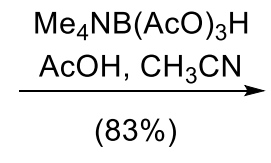

$(83 \%)$<smiles>[R7]OC([C@@H](C)/C([X])=C/C)[C@@H](C)/C(=C\C)O[Si]C</smiles>

44
1.

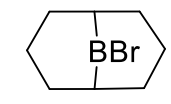
$\mathrm{CH}_{2} \mathrm{Cl}_{2}$<smiles>CCOCC(C=O)C(=O)[18O]</smiles>
$(81 \%)$

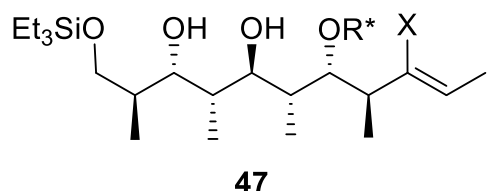

47<smiles>C[C@@H](CO)[C@H]1OC(C)(C)O[C@@H]([C@H](C)[C@H]2OC(C)(C)OC[C@H]2C)[C@H]1C</smiles>

$(-)-48(>99 \%$ ee $)$

Scheme 8. Expeditious asymmetric synthesis of Kishi's stereoheptad: formal total synthesis of rifamycin $\mathrm{S}$.

8. Generalization of the $\mathrm{SO}_{2}$-Induced Umpolung. Short Synthesis of the $\mathrm{C}_{16}-\mathrm{C}_{28}$ Fragment of Apoptolidinone: Formal Total Synthesis of Apoptolidin A

Apoptolidin A (isolated from Nocardiopsis sp.) $[143,144]$ and the natural analogues B, C, D, E and F [145-147] are leads for the chemotherapy of cancers [148-151]. They selectively induce apoptosis in cancer cells. The groups of Nicolaou [152,153] and Koert [154,155] have presented the first syntheses of apoptolidin A. The groups of Sulikowsky [156,157] and Crimmins [158] have reported syntheses of the aglycon apoptolidinone A. Fragments of this aglycon has been prepared by other groups [159].

Applying our $\mathrm{SO}_{2}$-induced Umpolung reaction, rapid access (nine steps) to Koert's $\mathrm{C}_{16}-\mathrm{C}_{28}$ polyketide fragment 57 (Scheme 9) of apoptolidinones $\mathrm{A}$ has been realized [160]. This work illustrates that other dienes and enoxysilanes than those presented in Scheme 1 can be used in our reaction cascade. Fragment $\mathbf{5 7}$ is adequately protected for the glycosidation steps necessary in the construction of apoptolidin A. 
<smiles>[R]OC=C(C)C=CC</smiles>

49: $\mathrm{R}^{\prime}=(R)-1-$ phenylethyl 50 $\mathrm{Tf}=\mathrm{CF}_{3} \mathrm{SO}_{2}$
1. $\mathrm{SO}_{2}, \mathrm{Tf}_{2} \mathrm{NH}$

$\stackrel{\mathrm{CH}_{2} \mathrm{Cl}_{2},-78{ }^{\circ} \mathrm{C}}{\longrightarrow}$

2. $\mathrm{Et}_{3} \mathrm{~N}, i-\mathrm{PrOH}$, $\mathrm{MeCN}, 80^{\circ} \mathrm{C}$

$(71 \%)$<smiles>[R10]C([C@@H](C)C=CC)[C@@H](C)C(C)=O</smiles>

TBSOTf, $\mathrm{Et}_{3} \mathrm{~N}$

$\underset{\text { then } m \text { CPBA }}{\stackrel{\mathrm{CH}_{2} \mathrm{Cl}_{2}, 0^{\circ} \mathrm{C}}{\longrightarrow}}$

$(75 \%)$

$51 \quad \mathrm{TBS}=t-\mathrm{BuMe}_{2} \mathrm{Si}$

$$
m \mathrm{CPBA}=3-\mathrm{ClC}_{6} \mathrm{H}_{4} \mathrm{CO}_{3} \mathrm{H}
$$

1. NaHDMS, THF, $-78{ }^{\circ} \mathrm{C}$
$\mathrm{Me}_{3} \mathrm{SiCl}$

$53 \quad(73 \%)$

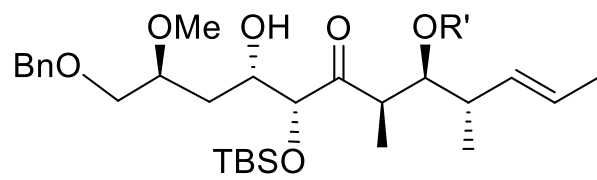

54
1. $\mathrm{O}_{3}, \mathrm{NaHCO}_{3}, \mathrm{CH}_{2} \mathrm{Cl}_{2},-78{ }^{\circ} \mathrm{C}$ then $\mathrm{Me}_{2} \mathrm{~S},-78$ to $-20^{\circ} \mathrm{C}$

2. (+)-(lpc $)_{2}$ Ballyl, $\mathrm{Et}_{2} \mathrm{O},-78^{\circ} \mathrm{C}$ $(78 \%)$

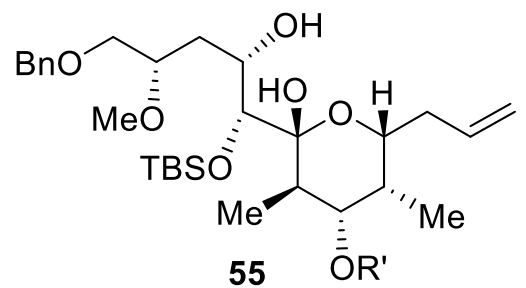

1. $\mathrm{HCl}, \mathrm{MeOH}, 20^{\circ} \mathrm{C}$ then $\mathrm{Ac}_{2} \mathrm{O}$, pyridine $0-20^{\circ} \mathrm{C}$

2. TESCI, imidazole, $\mathrm{CH}_{2} \mathrm{Cl}_{2}, 20^{\circ} \mathrm{C}$ (76\%)<smiles>C=CC[C@H]1O[C@](O)([C@@H](C[C@@H](COCc2ccccc2)OC(C)=O)OC(C)=O)[C@H](C)[C@H]([O+]=S)[C@@H]1C</smiles>

56
1. (DHQD) $)_{2} \mathrm{PYR}$, $\mathrm{K}_{2} \mathrm{OsO}_{4} \cdot 2 \mathrm{H}_{2} \mathrm{O}$ cat., $\stackrel{\mathrm{K}_{3} \mathrm{Fe}(\mathrm{CN})_{6}, \mathrm{~K}_{2} \mathrm{CO}_{3},}{t-\mathrm{BuOH} / \mathrm{H}_{2} \mathrm{O}, 0^{\circ} \mathrm{C}}$

2. Mel, $\mathrm{Ag}_{2} \mathrm{O}, \mathrm{DMF}, 20^{\circ} \mathrm{C}$

$(68 \%)$

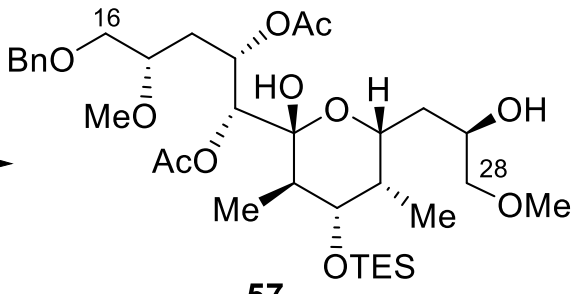

57

Scheme 9. Synthesis of Koert's $C_{16}-C_{28}$ polyketide fragment of apoptolidin A.

Diene 49 (derived from inexpensive ( $R$ )-1-phenylethanol) and silyl ethers 50 (1:1 E/Z mixture) were reacted with a catalytic amount of $\left(\mathrm{CF}_{3} \mathrm{SO}_{2}\right)_{2} \mathrm{NH}$ in $\mathrm{SO}_{2} / \mathrm{CH}_{2} \mathrm{Cl}_{2}$ (5:1) cooled to $-78{ }^{\circ} \mathrm{C}$. After neutralization of the acid catalyst with $\mathrm{Et}_{3} \mathrm{~N}$ and solvent evaporation, alcoholysis with $i-\operatorname{PrOH}\left(80^{\circ} \mathrm{C}\right)$ gave a $4: 1$ mixture of stereotriad 51 and its $\alpha, \beta, \gamma$-anti,ant $i$ stereomer. This mixture was converted into their kinetic silyl enol ethers and oxidized with $m$ CPBA (Rubottom oxidation [161]) giving 52 that underwent Mukaiyama aldol coupling with aldehyde 53 [162,163], producing alkene 54 . Ozonolysis of 54 followed by treatment with $\mathrm{Me}_{2} \mathrm{~S}$ gave an aldehyde that was allylated under Brown's conditions [164]. The resulting homoallylic alcohol was equilibrated with the hemiacetal $\mathbf{5 5}$ that underwent desilylation, debenzylation and Fischer glycosidation on treatment with $\mathrm{HCl} / \mathrm{MeOH}$ at $50{ }^{\circ} \mathrm{C}$. The resulting triol was then acetylated selectively into a diacetate (at $C_{19}$ and $C_{20}$ ); the most sterically hindered alcohol at $C_{23}$ was then silylated giving 56 . Sharpless asymmetric dihydroxylation [165] of 56 furnished a 4.5:1 mixture of the corresponding diol that was selectively monomethylated with $\mathrm{MeI} / \mathrm{Ag}_{2} \mathrm{O}$ giving Koert's intermediate 57.

9. The One-Pot Four-Component Synthesis of Polyfunctional Sulfones: Application to a Short Synthesis of the $\mathrm{C}_{1}-\mathrm{C}_{11}$ Fragment of Apoptolidin A

Another key intermediate in the total synthesis of apoptolidin A is the Nicolaou's $\mathrm{C}_{1}-\mathrm{C}_{11}$-fragment (+)-65 the preparation of which requires 11 steps [152]. Applying our $\mathrm{SO}_{2}-$ induced Umpolung reaction, an expeditious synthesis of this intermediate was realized with an overall yield of $29 \%$ starting with simple diene 58 , enoxysilane 59 and the known enantiomerically pure (S)-3-methoxymethoxy-2-methylprop-1-yl iodide. The method required the isolation of only three synthetic intermediates (Scheme 10) [166]. In the 
presence of 0.4 equivalent of a strong acid such as $\left(\mathrm{CF}_{3} \mathrm{SO}_{2}\right)_{2} \mathrm{NH}$ sulfur dioxide adds to the s-trans form of diene 58 equilibrating with a zwitterionic intermediate 60 that was quenched by the enoxysilane 59. One assumes that another zwitterionic intermediate 61 was formed, which after treatment with tetrabutylammonium fluoride generated the dihydroxyketone $\mathbf{6 2}$, an aldol that loses one equivalent of water under acidic conditions ( $p$-TsOH, $\mathrm{MeOH}, 70{ }^{\circ} \mathrm{C}$ ) to give the $(E, E)$-dienone 63 (one pot: $87 \%$ yield). Silyl ether and enol silyl ether formation was followed by oxidation with $m$ CPBA. This generated an $\alpha-$ hydroxyketone which was not isolated but directly submitted to the Malaprade oxidation, giving a carboxylic acid that was esterified in situ with diazomethane-producing ester 64 . Dess-Martin oxidation of the primary alcohol of $\mathbf{6 4}$ gave an aldehyde that was reacted, without purification, with $\mathrm{Et}_{3} \mathrm{SiCC}$-Li to give a 5:1 mixture of diastereomeric propargylic alcohols. They were silylated and the sulfone moiety underwent a Ramberg-Bäcklund rearrangement [167-169] providing a 12:1 mixture of $(E, E, E)-/(E, E, Z)$-triene-ester (+)-65.

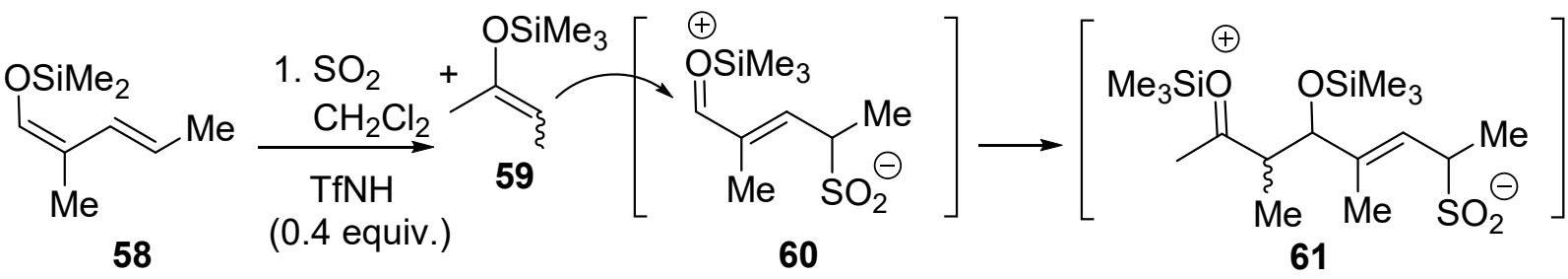

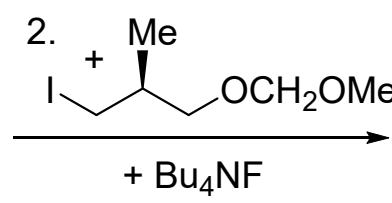

3. $\mathrm{TsOH}, \mathrm{MeOH}, 70^{\circ} \mathrm{C}$<smiles>COC(=O)/C(C)=C/C(C)=C/[C@@H]([C@@H](C)CS(=O)(=O)C[C@@H](C)CO)S(=O)(=O)C[C@@H](C)CO</smiles>

64
1. TBSOTf, $\mathrm{Et}_{3} \mathrm{~N},-10^{\circ} \mathrm{C}$ then $+\mathrm{Me}_{3} \mathrm{SiOTf},-40^{\circ} \mathrm{C}$

2. $m \mathrm{CPBA}, \mathrm{CH}_{2} \mathrm{Cl}_{2}, 10^{\circ} \mathrm{C}$

3. $\mathrm{NaIO}_{4}, 20^{\circ} \mathrm{C}$

4. $\mathrm{CH}_{2} \mathrm{~N}_{2}$ (one pot: $66 \%$ )<smiles>CC[Sb]C#CC([OH2+])[C@@H](C)/C=C(C)/C=C(C)/C=C(\C)C(=O)OC</smiles>

1. Dess-Martin periodinane

2. $+\mathrm{Et}_{3} \mathrm{SiCCLi}$ (one pot: $71 \%$ )

3. TBSCl, imidazole, $\mathrm{DMF}, 0^{\circ} \mathrm{C}$

4. $\mathrm{KOH} / \mathrm{Al}_{2} \mathrm{O}_{3}, \mathrm{CF}_{2} \mathrm{Br}_{2}, \mathrm{CH}_{2} \mathrm{Cl}_{2}$, $40^{\circ} \mathrm{C}$ (one pot: $72 \%$ )

$(+)-65(E, E, E) /(E, E, Z) 12: 1$; ee $>99 \%$

Scheme 10. An expeditious synthesis of the Nicolaou's $C_{1}-C_{11}$ fragment of apoptolidin A.

\section{Allylsilanes as Nucleophiles: Development of Two-Directional Polypropionate-Polyketide Synthesis}

Like enol silyl ethers, allylsilanes are nucleophiles that can be used in our $\mathrm{SO}_{2}$-induced CC bond-forming reaction. Using allyldisilane 67 and two different dienes, 66 and 69 , the stereotetrads 70 can be prepared in one-pot operations (Scheme 11). Diene 66 possesses a 1-(1-phenyl)ethoxy group whereas diene bears a 1-[1-(4-fluorophenyl]ethoxy substituent. The $\mathrm{S}_{\mathrm{N}} 1$ and $\mathrm{E}_{1}$ cleavage of the benzylic $\mathrm{C}-\mathrm{O}$ ether bond of the 1-phenylethoxy group are faster than the $\mathrm{S}_{\mathrm{N}} 1$ and $\mathrm{E}_{1} \mathrm{C}-\mathrm{O}$ benzylic bond cleavage of the 1-(4-fluorophenyl)ethoxy group; the pseudo-symmetrical stereotetrad is suitable for two successive aldol reactions on both their chain terminus. This permits the expeditious syntheses of long-chain polyketides and polypropionates. 


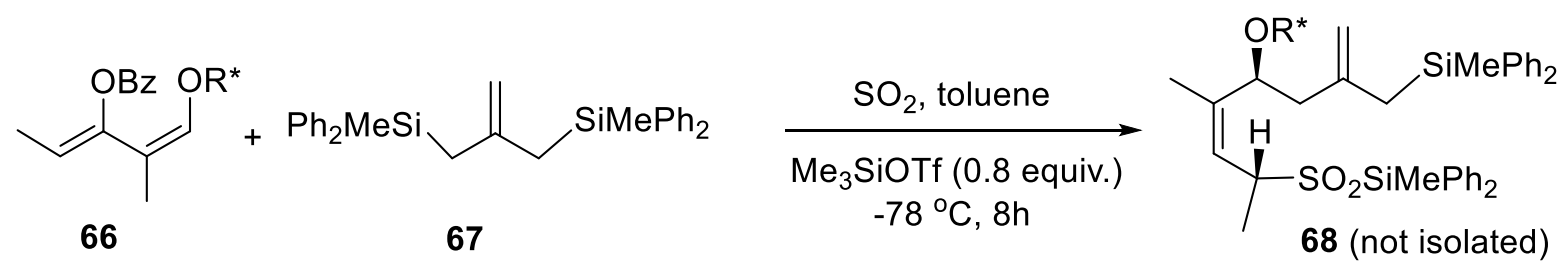

$R^{*}=(S)$-1-phenylethyl

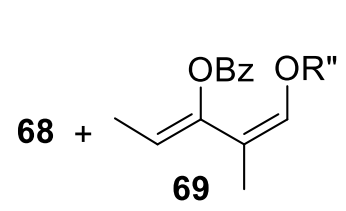

$$
\text { 1. }-78^{\circ} \mathrm{C}, 15 \mathrm{~h}
$$

2. $\mathrm{K}_{2} \mathrm{CO}_{3}, \mathrm{MeCN}$,

68

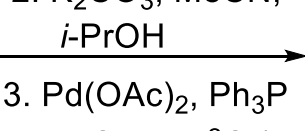

$\mathrm{MeCN}, 80^{\circ} \mathrm{C}(54 \%)$
1. $\mathrm{BCl}_{3}, \mathrm{Me}_{5} \mathrm{C}_{6} \mathrm{H}$

$\mathrm{CH}_{2} \mathrm{Cl}_{2},-78^{\circ} \mathrm{C}$

2. $\mathrm{LiN}\left(\mathrm{SiMe}_{3}\right)_{3}$

THF, $-78{ }^{\circ} \mathrm{C}$ $\mathrm{R}^{\prime \prime}=(R)-1-\left(4-\mathrm{CF}_{3} \mathrm{C}_{6} \mathrm{H}_{4}\right)$ ethyl

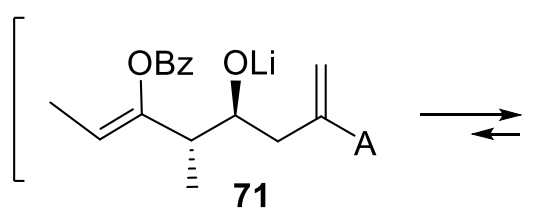

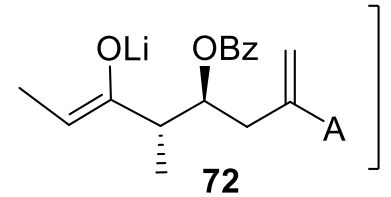

1. $\mathrm{Me}_{3} \mathrm{SiCl}$

2. $i-\mathrm{PrCHO}, \mathrm{BF}_{3} \cdot \mathrm{Et}_{2} \mathrm{O}, \mathrm{CH}_{2} \mathrm{Cl}_{2}$

$-78^{\circ} \mathrm{C}(72 \%)$

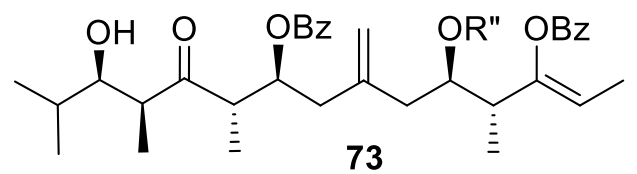

1. $\mathrm{Et}_{2} \mathrm{BOMe}, \mathrm{NaBH}_{4}, \mathrm{MeOH}, \mathrm{THF},-78{ }^{\circ} \mathrm{C}$

2. $\mathrm{NaHCO}_{3}, \mathrm{H}_{2} \mathrm{O}_{2}, \mathrm{MeOH}, 5^{\circ} \mathrm{C}$

3. $(\mathrm{MeO})_{2} \mathrm{CMe}_{2}, p-\mathrm{TsOH}, 25^{\circ} \mathrm{C}(83 \%)$

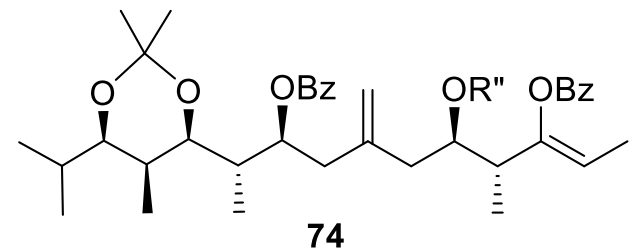

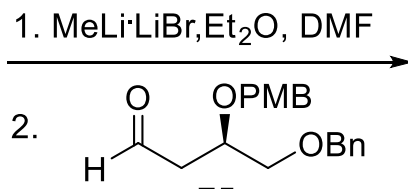<smiles>CC(C)(C)O[Mg]O[Mg]</smiles>

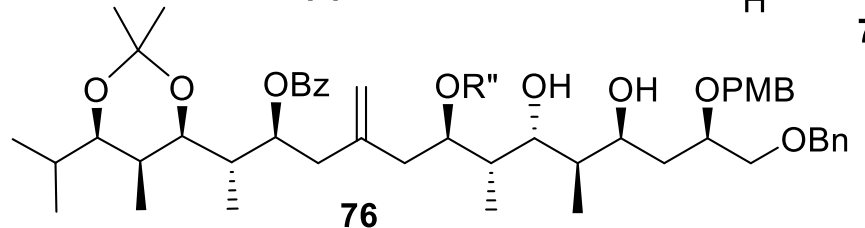

75

$$
\begin{aligned}
& \mathrm{Bz}=\mathrm{PhCO} \\
& \mathrm{PMB}=4-\mathrm{MeOC}_{6} \mathrm{H}_{4} \mathrm{CH}_{2} \\
& \mathrm{Bn}=\mathrm{PhCH}_{2}
\end{aligned}
$$

Scheme 11. Convergent synthesis of complicated polypropionate-polyketide fragments through dissymmetrical twodirectional chain elongation.

Reaction of diene 66 with 67 and $\mathrm{SO}_{2}$ promoted by $\mathrm{Me}_{3} \mathrm{SiOTf}$ generated the product of mono-alkoxyallylation 68 . The reaction $66+67 \rightarrow 68$ is faster than the reaction of monoallysilane 68 with diene $67+\mathrm{SO}_{2}$ because bisallylsilane 66 enjoys twice the $\beta$-silicon effect. In the presence of one equivalent of diene $\mathbf{6 6}$ the product of double oxyallytion is not formed; only sulfinate $\mathbf{6 8}$ is formed. It can be reacted without purification with $\mathrm{SO}_{2}$ and diene 69, providing a bis(silyl sulfinate) which is not isolated but submitted directly to the double $\mathrm{Pd}^{(0)}$-catalyzed desilylation and desulfitation reactions, furnishing the stereotetrad $\mathbf{7 0}$, isolated in $54 \%$ yield (one-pot). Selective debenzylation of $\mathbf{7 0}$ with $\mathrm{BCl}_{3}$ / pentamethylbenzene eliminated the phenylethyl group, giving a homoallylic alcohol that was not isolated but treated directly with $\left(\mathrm{Me}_{3} \mathrm{Si}\right)_{2} \mathrm{NLi}$ to engender the corresponding lithium alcoholate $\mathbf{7 1}$ (one pot). The latter underwent rapid acyl group migration from the neighboring enol benzoate forming lithium enolate $\mathbf{7 2}$. Without isolation, the latter enolate reacted with $\mathrm{Me}_{3} \mathrm{SiCl}$ giving a $(Z)$-enoxysilane that was reacted in situ with isobutyraldehyde and $\mathrm{BF}_{3}$ etherate, providing aldol 73 which was a single stereomer isolated in $72 \%$ yield. Reduction of aldol 72 under Narasaka's conditions [170] gave the corresponding syn-1,3-diol that was converted in situ into its acetonide 74 (83\%, overall). The treatment 
of enol benzoate $\mathbf{7 4}$ with $\mathrm{MeLi} \mathrm{LiBr}$ furnished the corresponding lithium (Z)-enolate. It was quenched by the chiral aldehyde 75 producing a major aldol that was not isolated but directly reduced under Evans' conditions $[88,89]$. This furnished $\mathbf{7 6}$, a polyketides containing 11 stereogenic centers. As the configuration of the 1-oxydienes 66 and 69 can be either $(R)$ or $(S)$ and since the two successive aldol reactions on the intermediate stereotetrad can used a wide variety of aldehydes under well-chosen conditions, a very large library of polyketides can be prepared applying our method illustrated in Scheme 11 [171,172].

\section{Conclusions}

At low temperature, and in the presence of a protic or Lewis acid catalyst, 1-alkoxy1,3-dienes undergo fast hetero-Diels-Alder reactions with $\mathrm{SO}_{2}$, forming unstable sultines that are converted rapidly into zwitterionic intermediates containing 1-oxyallyl cation moieties. The latter are quenched in situ by electron-rich alkenes such as silyl enol ethers generating $\beta, \gamma$-unsaturated silyl sulfinates. Sufur dioxide induces a stereoselective $C-C$ bond forming reactions between electron-rich dienes and alkenes (Umpolung through $\mathrm{SO}_{2}$ ). The silyl sulfinates so obtained can be converted in situ into stereotriads that are flanked by an ethyl ketone group at one side and by an enol ester of an ethyl ketone on the other side. In a few synthetic steps the synthesis of the cyclohexanone unit of baconipyrones and of the two fragments of (-)-dolabriferol have been realized. With the first total synthesis of (-)-dolabriferol we could establish its absolute configuration. Aldol condensation of the ethyl ketone group of one of our stereotriads has opened a very short route to Kishi's stereoheptad, which he used to construct rifamycin-S. A similar strategy has permitted us to obtain the Koert's $C_{16}-C_{28}$ polyketide fragment of apoptolidin A. Under strongly acidic conditions, s-trans-1-alkoxydienes and enoxysilanes react with $\mathrm{SO}_{2}$ forming sulfinates that are quenched in situ with electrophiles to generate polyfunctional sulfones with a conjugated $(E, E)$-dienone moiety. The method has permitted an efficient synthesis of Nicolaou's $C_{1}-C_{11}$ fragment of apoptolidin A. The stereotriads undergo two successive metal aldol reactions that produce complicated polyketides and polypropionates in a few steps. Allylsilanes can be used instead of enoxysilanes in our $\mathrm{SO}_{2}$-induced Umpolung reaction. With 2-[(methyldiphenyl)methyl]allylmethyl(diphenyl)silane), two successive alkoxyallylations with two different 1-alkoxydienes can be run in the same pot, thus generating stereotetrads ready for two successive aldol reactions (two-directional chain elongations). The strategy permits us to construct, in a few steps, complicated polyketides and polypropionates in a combinatorial fashion.

Funding: The research was financed by the University of Lausanne, the Ecole Polytechnique Fédérale de Lausanne (EPFL), the Swiss National Science Foundation and the University of Oviedo.

Acknowledgments: The authors wish to gratefully thank all their former co-workers for their intellectual input and their fantastic experimental studies. Their names appear in the citations.

Conflicts of Interest: The authors declare no conflict of interest.

\section{References}

1. Davies-Coleman, M.T.; Garson, M.J. Marine polypropionates. Nat. Prod. Rep. 1998, 15, 477-493. [CrossRef]

2. Müller, W.E.G. Marine Molecular Biotechnology; Springer: Berlin, Germany, 2006; Chapter 1.2; Volume 71, pp. 570-575.

3. Liu, Z.; Liu, H.; Zhang, W. Natural Polypropionates in 1999-2020: An Overview of Chemical and Biological Diversity. Mar. Drugs 2020, 18, 569. [CrossRef]

4. Wu, Q.; Li, S.-W.; Xu, H.; Wang, H.; Hu, P.; Zhang, H.; Luo, C.; Chen, K.-X.; Nay, B.; Guo, Y.-W.; et al. Complex polypropionates from a South China Sea photosynthetic mollusk: Isolation and biomimetic synthesis highlighting novel rearrangements. Angew. Chem. Int. Ed. 2020, 59, 12105-12112. [CrossRef] [PubMed]

5. Wang, B.; Chen, D.; Yu, M.; Liu, Y.; Liu, P.; Zhang, X. A Review on Metabolites from Onchidium Genus: Chemistry and Bioactivity. Chem. Biodivers. 2020, 18, e2000580. [CrossRef]

6. Lin, S.; Wu, Y.-Z.; Chen, K.-Y.; Ye, J.; Yang, X.-W.; Zhang, W.-D. Polyketides from the fungus Penicillium decumbens. J. Asian Nat. Prod. Res. 2018, 20, 445-450. [CrossRef]

7. Koskinen, A.M.P.; Karisalmi, K. Polyketide stereotetrads in natural products. Chem. Soc. Rev. 2005, 34, 677-690. [CrossRef]

8. Hertweck, C. The Biosynthetic Logic of Polyketide Diversity. Angew. Chem. Int. Ed. 2009, 48, 4688-4716. [CrossRef] [PubMed] 
9. Weissman, K.J.; Leadlay, P. Combinatorial biosynthesis of reduced polyketides. Nat. Rev. Genet. 2005, 3, 925-936. [CrossRef] [PubMed]

10. Walsh, C.T. Nature Builds Macrocycles and Heterocycles into Its Antimicrobial Frameworks: Deciphering Biosynthetic Strategy. ACS Infect. Dis. 2018, 4, 1283-1299. [CrossRef] [PubMed]

11. Cragg, G.M.; Grothaus, P.G.; Newman, D.J. Impact of Natural Products on Developing New Anti-Cancer Agents. Chem. Rev. 2009, 109, 3012-3043. [CrossRef] [PubMed]

12. Panek, J.S.; Jain, N.F. Total Synthesis of Rutamycin B and Oligomycin C. J. Org. Chem. 2001, 66, 2747-2756. [CrossRef]

13. Crossman, J.S.; Perkins, M.V. Total Synthesis and Structural Elucidation of (-)-Maurenone. J. Org. Chem. 2005, 71, 117-124. [CrossRef]

14. Ward, D.E. The thiopyran route to polypropionates. Chem. Commun. 2011, 47, 11375-11393. [CrossRef]

15. Ward, D.E.; Kazemeini, A. Aldol Reactions with Kinetic Resolution: Scope and Limitations of Ketal- and Dithioketal-Protected ß-Ketoaldehydes. J. Org. Chem. 2012, 77, 10789-10803. [CrossRef]

16. Turks, M.; Laclef, S.; Vogel, P. Construction of Polypropionate Fragments in Natural Product Synthesis. Stereoselective Synthesis of Drugs and Natural Products; John Wiley \& Sons, Inc.: Hoboken, NJ, USA, 2013; Volume 1, pp. 271-318.

17. Alagiri, K.; Lin, S.; Kumagai, N.; Shibasaki, M. Iterative Direct Aldol Strategy for Polypropionates: Enantioselective Total Synthesis of (-)-Membrenone A and B. Org. Lett. 2014, 16, 5301-5303. [CrossRef] [PubMed]

18. Miles, W.H.; Madison, C.M.; Mastria, M.L.; Tang, P.-I. Synthesis of the C3-C7 fragment of tylonolide by the $\gamma$-hydroxybutenolide approach. Tetrahedron Lett. 2016, 57, 3929-3932. [CrossRef]

19. Hosokawa, S. Remote Asymmetric Induction Reactions using a E,E-Vinylketene Silyl N,O-Acetal and the Wide Range Stereocontrol Strategy for the Synthesis of Polypropionates. Acc. Chem. Res. 2018, 51, 1301-1314. [CrossRef] [PubMed]

20. Santana, C.G.; Krische, M.J. From Hydrogenation to Transfer Hydrogenation to Hydrogen Auto-Transfer in Enantioselective Metal-Catalyzed Carbonyl Reductive Coupling: Past, Present, and Future. ACS Catal. 2021, 11, 5572-5585. [CrossRef] [PubMed]

21. Dechert-Schmitt, A.-M.R.; Schmitt, D.C.; Gao, X.; Itoh, T.; Krische, M.J. Polyketide construction via hydrohydroxyalkylation and related alcohol C-H functionalizations: Reinventing the chemistry of carbonyl addition. Nat. Prod. Rep. 2014, 31, 504-513. [CrossRef] [PubMed]

22. Feng, J.; Kasun, Z.A.; Krische, M.J. Enantioselective Alcohol C-H Functionalization for Polyketide Construction: Unlocking Redox-Economy and Site-Selectivity for Ideal Chemical Synthesis. J. Am. Chem. Soc. 2016, 138, 5467-5478. [CrossRef] [PubMed]

23. Nguyen, K.D.; Park, B.Y.; Luong, T.; Sato, H.; Garza, V.J.; Krische, M.J. Metal-catalyzed reductive coupling of olefin-derived nucleophiles: Reinventing carbonyl addition. Science 2016, 354, aah5133. [CrossRef] [PubMed]

24. Kim, S.W.; Zhang, W.; Krische, M.J. Catalytic Enantioselective Carbonyl Allylation and Propargylation via Alcohol-Mediated Hydrogen Transfer: Merging the Chemistry of Grignard and Sabatier. Acc. Chem. Res. 2017, 50, 2371-2380. [CrossRef] [PubMed]

25. Holmes, M.; Schwartz, L.A.; Krische, M.J. Intermolecular Metal-Catalyzed Reductive Coupling of Dienes, Allenes, and Enynes with Carbonyl Compounds and Imines. Chem. Rev. 2018, 118, 6026-6052. [CrossRef] [PubMed]

26. Liu, H.; Lin, S.; Jacobsen, K.M.; Poulsen, T.B. Chemical Syntheses and Chemical Biology of Carboxyl Polyether Ionophores: Recent Highlights. Angew. Chem. Int. Ed. 2019, 58, 13630-13642. [CrossRef] [PubMed]

27. Doerksen, R.S.; Meyer, C.C.; Krische, M.J. Feedstock Reagents in Metal-Catalyzed Carbonyl Reductive Coupling: Minimizing Preactivation for Efficiency in Target-Oriented Synthesis. Angew. Chem. Int. Ed. 2019, 58, 14055-14064. [CrossRef] [PubMed]

28. Siu, Y.-M.; Roane, J.; Krische, M.J. Total Synthesis of Leiodermatolide A via Transfer Hydrogenative Allylation, Crotylation, and Propargylation: Polyketide Construction beyond Discrete Allyl- or Allenylmetal Reagents. J. Am. Chem. Soc. 2021, 143, 10590-10595. [CrossRef]

29. Li, J.; Menche, D. Direct methods for stereoselective polypropionate synthesis: A survey. Synthesis 2009, 14, $2293-2315$.

30. Solsona, J.G.; Romea, A.P.; Urpí, F. Studies Directed toward the Construction of the Polypropionate Fragment of Superstolide A. Org. Lett. 2003, 5, 4681-4684. [CrossRef]

31. Yadav, J.S.; Srinivas, R.; Sathaiah, K. Total synthesis of natural (+)-membrenone C and its 7-epimer. Tetrahedron Lett. 2006, 47, 1603-1606. [CrossRef]

32. Chandra, B.; Fu, D.; Nelson, S.G. Catalytic Asymmetric Synthesis of Complex Polypropionates: Lewis Base Catalyzed Aldol Equivalents in the Synthesis of Erythronolide B. Angew. Chem. Int. Ed. 2010, 49, 2591-2594. [CrossRef]

33. Mochirian, P.; Godin, F.; Katsoulis, I.; Fontaine, I.; Brazeau, J.-F.; Guindon, Y. A Bidirectional Approach to the Synthesis of Polypropionates: Synthesis of C1-C13 Fragment of Zincophorin and Related Isomers. J. Org. Chem. 2011, 76, 7654-7676. [CrossRef]

34. Brady, P.B.; Yamamoto, H. Rapid and Stereochemically Flexible Synthesis of Polypropionates: Super-Silyl-Governed Aldol Cascades. Angew. Chem. Int. Ed. 2012, 51, 1942-1946. [CrossRef]

35. Becerril-Jiménez, F.; Ward, D.E. On the Origin of Siphonariid Polypropionates: Total Synthesis of Caloundrin B and Its Isomerization to Siphonarin B. Org. Lett. 2012, 14, 1648-1651. [CrossRef]

36. Ward, D.E. Polypropionate synthesis via substrate-controlled stereoselective aldol couplings of chiral fragments. In Modern Methods in Stereoselective Aldol Reactions; Mahrwald, R., Ed.; Wiley-VCH Verlag GmbH \& Co. KGaA: Weinheim, Germany, 2013; pp. 377-429.

37. Oshima, M.; Yamazaki, H.; Shimizu, I.; Nisar, M.; Tsuji, J. Palladium-catalyzed selective hydrogenolysis of alkenyloxiranes with formic acid. Stereoselectivity and synthetic utility. J. Am. Chem. Soc. 1989, 111, 6280-6287. [CrossRef]

38. Nagasawa, K.; Shimizu, I.; Nakata, T. ChemInform Abstract: Total Synthesis of Preswinholide A. Part 1. Stereoselective Synthesis of the C11-C23 Segment. ChemInform 2010, 28, 6881-6884. [CrossRef] 
39. Jung, M.E.; Chaumontet, M.; Salehi-Rad, R. Total Synthesis of Auripyrone B Using a Non-Aldol Aldol-Cuprate Opening Process. Org. Lett. 2010, 12, 2872-2875. [CrossRef]

40. Bandaru, A.; Kaliappan, K.P. Synthesis of the C1-C10 fragment of muamvatin. Chem. Asian J. 2020, 15, 2208-2211. [CrossRef]

41. Si, D.; Kaliappan, K.P. Synthesis of C9-C13 and C15-C21 subunits of discodermolide. Asian J. Org. Chem. 2020, 9, 1205-1212. [CrossRef]

42. Zacuto, M.J.; O'Malley, S.J.; Leighton, J.L. Tandem silylformylation-allyl(crotyl)silylation: A new approach to polyketide synthesis. Tetrahedron 2003, 59, 8889-8900. [CrossRef]

43. Foley, C.N.; Leighton, J.L. Beyond the Roche Ester: A New Approach to Polypropionate Stereotriad Synthesis. Org. Lett. 2014, 16, 1180-1183. [CrossRef] [PubMed]

44. Foley, C.N.; Leighton, J.L. A Highly stereoselective, efficient, and scalable synthesis of the C(1)-C(9) fragment of the epothilones. Org. Lett. 2015, 17, 5858-5861. [CrossRef] [PubMed]

45. Yang, L.; Kong, L.; Gu, Q.; Shao, S.; Lin, G.-Q.; Hong, R. Stereoselective Access to Polypropionates Expedited by the Double Hydroboration of Allenes: Total Synthesis of Antitumor (-)-Pironetin. CCS Chem. 2021, 3, 769-779. [CrossRef]

46. Bode, J.W.; Fraefel, N.; Muri, D.; Carreira, E.M. A General solution to the modular synthesis of polyketide building blocks by Kanemasa hydroxy-directed nitrile oxide cycloadditions. Angew. Chem. Int. Ed. 2001, 40, 2082-2085. [CrossRef]

47. Fader, L.D.; Carreira, E.M. Stereochemically Rich Pentaketides from Bis(isoxazolines): A General Strategy for Efficient Polyketide Synthesis. Org. Lett. 2004, 6, 2485-2488. [CrossRef]

48. Muri, D.; Carreira, E. Stereoselective Synthesis of Erythronolide A via Nitrile Oxide Cycloadditions and Related Studies. J. Org. Chem. 2009, 74, 8695-8712. [CrossRef]

49. Danishefsky, S.; Harvey, D.F. A new approach to polypropionates-Routes to subunits of nonensin and tirandamycin. J. Am. Chem. Soc. 1985, 107, 6647-6652. [CrossRef]

50. Danishefsky, S.J.; Myles, D.C.; Harvey, D.F. Expeditious synthesis of the polypropionate sector of rifamycin S by reiterative Diene-Aldehyde cyclocondensation reactions. J. Am. Chem. Soc. 1987, 109, 862-867. [CrossRef]

51. Vogel, P.; Sevin, A.-F.; Kernen, P.; Bialecki, M. 'Naked sugars of the second generation': Asymmetric synthesis of long-chain polypropionates and analogues starting with acetone. Pure Appl. Chem. 1996, 68, 719-722. [CrossRef]

52. Vogel, P.; Cossy, J.; Plumet, J.; Arjona, O. Derivatives of 7-oxabicyclo[2.2.1]heptane in nature and as useful synthetic intermediates. Tetrahedron 1999, 55, 13521-13642. [CrossRef]

53. Arjona, O.; Menchaca, R.; Plumet, J. Building a small polypropionate library. Synthesis of all possible stereotetrads (building blocks for polyketide synthesis) from furan. J. Org. Chem. 2001, 66, 2400-2413. [CrossRef] [PubMed]

54. Arjona, O.; Plumet, J. The Ring Opening of Oxabicyclic Compounds Controlled by a Phenylsulfonyl Group: Synthetic Applications. ChemInform 2003, 34, 571-595. [CrossRef]

55. Hunt, K.W.; Grieco, P.A. Oxabicyclo[3.2.1]octenes in organic synthesis—Direct ring opening of oxabicyclo[3.2.1] systems employing silyl ketene acetals in concentrated solutions of lithium perchlorate-diethyl ether: Application to the synthesis of the C(19)-C(27) fragment of rifamycin S. Org. Lett. 2001, 3, 481-484. [PubMed]

56. Hagenbuch, J.-P.; Vogel, P. Asymmetric induction in the rearrangement of monocyclic endoperoxides into gamma-hydroxyalpha,beta-unsaturated aldehydes. J. Chem. Soc. Chem. Commun. 1980, 22, 1062-1063. [CrossRef]

57. Gesinski, M.R.; Brenzovich, W.E.; Staben, S.T.; Srinilta, D.J.; Toste, F.D. A divergent/convergent approach to dolabriferol: The Kornblum-DeLaMare enantiomeric resolution. Tetraedron Lett. 2015, 56, 3643-3646. [CrossRef]

58. Tokura, N. Olefin-sulfur dioxide copolymers. Encycl. Polym. Sci. Technol. 1968, 9, 460-485.

59. Gray, D.N. The status of olefin-sulfur dioxide copolymers as biomaterials. Polym. Sci. Technol. 1981, 14, 21-27.

60. Fawcett, A.H. Olefin-sulfur dioxide copolymers. Encycl. Polym. Sci. Eng. 1987, 10, 408-432.

61. Masilamani, D.; Reuman, M.E.; Rogic, M.M. Ene-type reaction through the intermediacy of the 1,4-dipolar ion in the reaction of tetracyanoethylene with nucleophilic double-bonds in liquid sulfur dioxide. J. Org. Chem. 1980, 45, 4602-4605. [CrossRef]

62. Masilamani, D.; Rogic, M.M. Organic reactions of sulfur dioxide. 4. Facile regiospecific hydrogen-deuterium exchange in olefins-Consequence of intermediacy of allylic sulfinic acids in ene reaction of sulfur dioxide with double bonds. J. Am. Chem. Soc. 1978, 100, 4634-4635. [CrossRef]

63. Marković, D.; Vogel, P. Polysulfones: Catalysts for Alkene Isomerization. Angew. Chem. Int. Ed. 2004, 43, 2928-2930. [CrossRef]

64. Markovic, D.; Vogel, P. Allyl, Methallyl, Prenyl, and Methylprenyl Ethers as Protected Alcohols: Their Selective Cleavage with Diphenyldisulfone under Neutral Conditions. Org. Lett. 2004, 6, 2693-2696. [CrossRef]

65. Marković, D.; Varela-Álvarez, A.; Sordo, J.A.; Vogel, P. Mechanism of the Diphenyldisulfone-Catalyzed Isomerization of Alkenes. Origin of the Chemoselectivity: Experimental and Quantum Chemistry Studies. J. Am. Chem. Soc. 2006, 128, 7782-7795. [CrossRef]

66. Backer, H.J.; Strating, J. Cyclical sulphones, derivatives and butadienes. Recl. Trav. Chim. Pays-Bas 1934, 53, 525-543. [CrossRef]

67. Heldeweg, R.F.; Hogeveen, H. $(2+4)(\pi+\pi, \pi)$ and $(2+4)(\mathrm{n}+\pi-\pi)$ modes of addition in reaction between SO2 and a diene- $-\mathrm{Kinetic}$ vs thermodynamic control. J. Am. Chem. Soc. 1976, 98, 2341-2342. [CrossRef]

68. Durst, T.; Tetreault-Ryan, L. Reaction of ortho-quinodimethane with sulfur dioxide. Competition between $\pi+\pi-\pi$ and $\mathrm{n}+\pi-\pi$ cycloadditions. Tetrahedron Lett. 1978, 26, 2353-2354. [CrossRef]

69. Deguin, B.; Vogel, P. Hetero-Diels-Alder addition of sulfur dioxide to 1,3-dienes. Suprafaciality, regioselectivity, and stereoselectivity. J. Am. Chem. Soc. 1992, 114, 9210-9211. [CrossRef]

70. Fernandez, T.; Sordo, J.A.; Monnat, F.; Deguin, B.; Vogel, P. Sulfur dioxide promotes its hetero-Diels-Alder and cheletropic additions to 1,2-dimethylenecyclohexane. J. Am. Chem. Soc. 1998, 120, 13276-13277. [CrossRef] 
71. Monnat, F.; Vogel, P.; Rayón, V.M.; Sordo, J.A. Ab Initio and Experimental Studies on the Hetero-Diels-Alder and Cheletropic Additions of Sulfur Dioxide to (E)-1-Methoxybutadiene: A Mechanism Involving Three Molecules of $\mathrm{SO}_{2}$. J. Org. Chem. 2002, 67, 1882-1889. [CrossRef] [PubMed]

72. Vogel, P.; Sordo, J. Hetero-Diels-Alder and Cheletropic Additions of Sulfur Dioxide to Conjugated Dienes. Experimental Facts and Theoretical Analysis. Curr. Org. Chem. 2006, 10, 2007-2036. [CrossRef]

73. Markovic, D.; Roversi, E.; Scoppelliti, R.; Vogel, P.; Meana, R.; Sordo, J.A. The hetero-Diels-Alder addition of sulfur dioxide: The pseudo-chair conformation of a 4,5-dialkylsultine. Chem. Eur. J. 2003, 9, 4911-4915. [CrossRef] [PubMed]

74. Monnat, F.; Vogel, P.; Meana, R.; Sordo, J.A. Equilibrium and Kinetic Deuterium Isotope Effects on the Hetero-Diels-Alder Addition of Sulfur Dioxide. Angew. Chem. Int. Ed. 2003, 42, 3924-3927. [CrossRef] [PubMed]

75. Roversi, E.; Scopelliti, R.; Solari, E.; Estoppey, R.; Vogel, P.; Braña, P.; Menéndez, B.; Sordo, J.A. The Hetero-Diels-Alder Addition of Sulfur Dioxide to 1-Fluorobuta-1,3-dienes: The Sofa Conformations Preferred by 6-Fluorosultines (6-Fluoro-3,6-dihydro-1,2oxathiin-2-oxides) Enjoy Enthalpic and Conformational Anomeric Effects. Chem. A Eur. J. 2002, 8, 1336-1355. [CrossRef]

76. Laclef, S.; Exner, C.J.; Turks, M.; Videtta, V.; Vogel, P. Synthesis of (E,Z)-1-Alkoxy-3-acyloxy-2-methylpenta-1,3-dienes via Danishefsky-Type Dienes or O-Acylation of Enones. J. Org. Chem. 2009, 74, 8882-8885. [CrossRef] [PubMed]

77. Vogel, P.; Turks, M.; Exner, C.; Hamel, C. Umpolung with Sulfur Dioxide: Carbon-Carbon Cross-Coupling of Electron-Rich 1,3-Dienes and Alkenes; Application to the Enantioselective Synthesis of Long-Chain Polyketide Fragments. Synthesis 2009, 2009, 1065-1074. [CrossRef]

78. Kanazawa, A.; Delair, P.; Pourashraf, M.; Greene, A.E. Convergent, enantioselective synthesis of the novel furanoditerpene (+)taonianone through facially selective chiral olefin-ketene [2+2] cycloaddition. J. Chem. Soc. Perkin Trans. 1997, 13, 1911-1912. [CrossRef]

79. Narkevitch, V.; Megevand, S.; Schenk, K.; Vogel, P. Development of a New Carbon-Carbon Bond Forming Reaction. New Organic Chemistry of Sulfur Dioxide. Asymmetric Four-Component Synthesis of Polyfunctional Sulfones. J. Org. Chem. 2001, 66, 5080-5093. [CrossRef] [PubMed]

80. Vogel, P.; Huang, X. One-Pot, Four-Component Synthesis of Polyfunctional Sulfones. Synthesis 2002, 2002, 0232-0236. [CrossRef]

81. Bouchez, L.C.; Dubbaka, S.R.; Turks, M.; Vogel, P. Sulfur Dioxide Mediated One-Pot, Three- and Four-Component Syntheses of Polyfunctional Sulfonamides and Sulfonic Esters: Study of the Stereoselectivity of the Ene Reaction of Sulfur Dioxide. J. Org. Chem. 2004, 69, 6413-6418. [CrossRef] [PubMed]

82. Bouchez, L.C.; Turks, M.; Dubbaka, S.R.; Fonquerne, F.; Craita, C.; Laclef, S.; Vogel, P. Sulfur dioxide mediated one-pot, fourcomponent synthesis of polyfunctional sulfones and sulfonamides, including medium-ring cyclic derivatives. Tetrahedron 2005, 61, 11473-11487. [CrossRef]

83. Vogel, P.; Turks, M.; Bouchez, L.; Craita, C.; Murcia, M.C.; Fonquerne, F.; Didier, C.; Huang, X.; Flowers, C. Use of sultines in the asymmetric synthesis of polypropionate antibiotics. Pure Appl. Chem. 2008, 80, 791-805. [CrossRef]

84. Turks, M.; Fairweather, K.A.; Scopelliti, R.; Vogel, P. Efficient Asymmetric Synthesis of Long-Chain Polyketides Containing up to Ten Contiguous Stereogenic Centres by Double Chain Elongation. Eur. J. Org. Chem. 2011, 2011, 3317-3328. [CrossRef]

85. Paterson, I.; Florence, G.J.; Gerlach, K.; Scott, J.; Sereinig, N. Total synthesis of the immunosuppressive agent (-)-discodermolide. J. Am. Chem. Soc. 2001, 123, 9535-9544. [CrossRef]

86. Paterson, I.; Perkins, M.V. Total Synthesis of (-)-Denticulatins A and B Using Efficient Methods of Acyclic Stereocontrol. Tetrahedron 1996, 52, 1811-1834. [CrossRef]

87. Stockdale, T.P.; Lam, N.Y.S.; Anketell, M.J.; Paterson, I. The Stereocontrolled Total Synthesis of Polyketide Natural Products: A Thirty-Year Journey. Bull. Chem. Soc. Jpn. 2021, 94, 713-731. [CrossRef]

88. Evans, D.A.; Chapman, K.T. The directed reduction of $\beta$-hydroxy ketones employing Me4NB(OAc)3H. Tetrahedron Lett. 1986, 27, 5939-5942. [CrossRef]

89. Evans, D.A.; Chapman, K.T.; Carreira, E.M. Directed reduction of beta.-hydroxy ketones employing tetramethylammonium triacetoxyborohydride. J. Am. Chem. Soc. 1988, 110, 3560-3578. [CrossRef]

90. Manker, D.C.; Faulkner, D.J.; Stout, T.J.; Clardy, J. The baconipyrones. Novel polypropionates from the pulmonate Siphonaria baconi. J. Org. Chem. 1989, 54, 5371-5374. [CrossRef]

91. Turks, M.; Murcia, M.C.; Scopelliti, R.; Vogel, P. First Asymmetric Synthesis of the Cyclohexanone Subunit of Baconipyrones A and B. Revision of Its Structure. Org. Lett. 2004, 6, 3031-3034. [CrossRef]

92. Pereyre, M.; Bellegarde, B.; Mendelsohn, J.; Valade, J. Action of triorganotin alkaloids on enol esters-Problem of obtaining C-or O-stannylated compounds. J. Organomet. Chem. 1968, 11, 97-110. [CrossRef]

93. Labadie, S.S.; Stille, J.K. Stereoselective aldol condensations of organotin reagents with aldehydes. Tetrahedron 1984, 40, 2329-2336. [CrossRef]

94. Ciavatta, M.L.; Gavagnin, M.; Puliti, R.; Cimino, G.; Martinez, E.; Ortea, J.; Mattia, C.A. Dolabriferol: A new polypropionate from the skin of the anaspidean mollusc Dolabrifera dolabrifera. Tetrahedron 1996, 52, 12831-12838. [CrossRef]

95. Paterson, I.; Chen, D.Y.K.; Acena, J.L.; Franklin, A.S. Studies in marine polypropionate synthesis: Total synthesis of (-)baconipyrone C. Org. Lett. 2000, 2, 1513-1516. [CrossRef]

96. Laclef, S.; Turks, M.; Vogel, P. Total Synthesis and Determination of the Absolute Configuration of (-)-Dolabriferol. Angez. Chem. Int. Ed. 2010, 49, 8525-8527. [CrossRef]

97. Currie, R.H.; Goodman, J.M. In Silico Inspired Total Synthesis of (-)-Dolabriferol. Angew. Chem. Int. Ed. 2012, 51, 4695-4697. [CrossRef]

98. Karagiannis, A.; Diddi, N.; Ward, D.E. On the Origin of Dolabriferol: Total Synthesis via Its Putative Contiguous Precursor. Org. Lett. 2016, 18, 3794-3797. [CrossRef] [PubMed] 
99. Gantasala, N.; Borra, S.; Pabbaraja, S.; Srihari, P. Stereoselective Total Synthesis of the Non-Contiguous Polyketide Natural Product (-)-Dolabriferol. Eur. J. Org. Chem. 2018, 2018, 1230-1240. [CrossRef]

100. Bandaru, A.; Si, D.; Kaliappan, K.P. Synthesis of C1-C9 and C10-C21 fragments of (-)-dolabriferol. Asian J. Org. Chem. 2020, 9 , 1045-1052. [CrossRef]

101. Rinehart, K.L. Antibiotics with ansa rings. Acc. Chem. Res. 1972, 5, 57-64. [CrossRef]

102. Rinehart, K.L.; Shield, S. Chemistry of the ansamycin antibiotics. Fortsch. Chem. Org. Naturst. 1976, 33, $231-307$.

103. Wehrli, W. Ansamycins Chemistry, biosynthesis and biological activity. Top. Curr. Chem. 1977, 72, 21-49.

104. Prelog, V. Conformation and reactivity of medium-sized ring compounds. Pure Appl. Chem. 1963, 6, 545-560. [CrossRef]

105. Sensi, P.; Furesz, S.; Maggi, G.; Maffi, G. Chemical modifications and biological properties of rifamycins. Antimicrob. Agents Chemother. 1966, 6, 699-714.

106. Arora, S.K. Correlation of structure and activity in ansamycins-Structure, conformation, and interactions of antibiotic rifamycin-S. J. Med. Chem. 1985, 28, 1099-1102. [CrossRef]

107. Joss, U.R.; Hughes, A.M.; Calvin, M. Effect of dimethylbenzyldesmethyl-rifamycin (Dmb) on chemically induced mammarytumors in rats. Nat.-New Biol. 1973, 242, 88-90. [CrossRef]

108. Spisani, S.; Traniello, S.; Martuccio, C.; Rizzuti, O.; Cellai, L. Rifamycins inhibit human neutrophil functions: New derivatives with potential antiinflammatory activity. Inflammation 1997, 21, 391-400. [CrossRef]

109. Hartmann, G.; Honikel, K.O.; Knüsel, F.; Nüesch, J. The specific inhibition of the DNA-directed RNA synthesis by rifamycin. Biochim. Biophys. Acta Nucleic Acids Protein Synth. 1967, 145, 843-844. [CrossRef]

110. Bacchi, A.; Pelizzi, G.; Nebuloni, M.; Ferrari, P. Comprehensive Study on Structure-Activity Relationships of Rifamycins: Discussion of Molecular and Crystal Structure and Spectroscopic and Thermochemical Properties of Rifamycin O. J. Med. Chem. 1998, 41, 2319-2332. [CrossRef]

111. Floss, H.G.; Yu, T.-W. Rifamycin-mode of action, resistance, and biosynthesis. Chem. Rev. 2005, 105, 621-632. [CrossRef]

112. O'Brien, R.J.; Lyle, M.A.; Snider, J.D.E. Rifabutin (Ansamycin LM 427): A New Rifamycin-S Derivative for the Treatment of Mycobacterial Diseases. Clin. Infect. Dis. 1987, 9, 519-530. [CrossRef]

113. Brogden, R.N.; Fitton, A. Rifabutin-A review of its antimicrobial activity, pharmacokinetic properties and therapeutic efficacy. Drugs 1994, 47, 983-1009. [CrossRef]

114. Barluenga, J.; Aznar, F.; García, A.B.; Cabal, M.P.; Palacios, J.J.; Menéndez, M.A. New rifabutin analogs: Synthesis and biological activity against mycobacterium tuberculosis. Bioorg. Med. Chem. Lett. 2006, 16, 5717-5722. [CrossRef]

115. Selva, E.; Lancini, G. Rifamycins, Antibacterial Antibiotics and Their New Applications; Fischer, J., Ganellin, C.R., Eds.; Analogue-Based Drug Discovery II; Wiley-VCH Verlag GmbH \& CO. KGaA: Weinheim, Germany, 2010; pp. 173-187.

116. Nagaoka, H.; Rutsch, W.; Schmid, G.; Iio, H.; Johnson, M.R.; Kishi, Y. Total synthesis of rifamycins. 1. Stereocontrolled synthesis of the aliphatic building block. J. Am. Chem. Soc. 1980, 102, 7962-7965. [CrossRef]

117. Iio, H.; Nagaoka, H.; Kishi, Y. Total synthesis of rifamycins. 2. Total synthesis of racemic rifamycin-S. J. Am. Chem. Soc. 1980, 102, 7965-7967. [CrossRef]

118. Kishi, Y. Total synthesis of rifamycin S. Pure Appl. Chem. 1981, 53, 1163-1180. [CrossRef]

119. Nagaoka, H.; Kishi, Y. Further synthetic studies on rifamycin s. Tetrahedron 1981, 37, 3873-3888. [CrossRef]

120. Hanessian, S.; Pougny, J.R.; Boessenkool, I.K. Total synthesis of the C19-C29 aliphatic segment of (+)-rifamycin-S. J. Am. Chem. Soc. 1982, 104, 6164-6166. [CrossRef]

121. Katsuki, T.; Hanamoto, T.; Yamaguchi, M. Synthesis of C19-C27Fragment of Ansa Chain Part of Rifamycin S. Chem. Lett. 1989, 18, 117-118. [CrossRef]

122. Paterson, I.; McClure, C.K.; Schumann, R.C. A short asymmetric synthesis of a C19-C27 segment of rifamycin S. Kinetic resolution in the aldol reactions of ethylketones using chiral boron reagents. Tetrahedron Lett. 1989, 30, 1293-1296. [CrossRef]

123. Chênevert, R.; Rose, Y.S. Enzymatic Desymmetrization of a Meso Polyol Corresponding to the C(19) -C(27) Segment of Rifamycin S. J. Org. Chem. 2000, 65, 1707-1709. [CrossRef]

124. Corey, E.J.; Hase, T. Studies on the total synthesis of rifamycin-Highly stereoselective synthesis of intermediates for construction of the C(15) to C(29) chain. Tetrahedron Lett. 1979, 4, 335-338. [CrossRef]

125. Masamune, S.; Imperiali, B.; Garvey, D.S. Synthesis of ansamycins: The ansa chain of rifamycin S. J. Am. Chem. Soc. 1982, 104, 5528-5531. [CrossRef]

126. Paterson, I.; Mansuri, M.M. Recent developments in the total synthesis of macrolide antibiotics. Chem. Informationsdienst 1985, 41, 3569-3624. [CrossRef]

127. Rao, A.V.R.; Yadav, J.S.; Vidyasagar, V. Stereoselective synthesis of the C-21 to C-27 segment of rifamycin-S. J. Chem. Soc. Chem. Commun. 1985, 55-56. [CrossRef]

128. Rao, A.V.R.; Yadav, J.S.; Vidyasagar, V. Stereoselective synthesis of the C-21 to C-27 segment of rifamycin-S. Tetrahedron Lett. 1986, 27, 3297-3298. [CrossRef]

129. Roush, W.R.; Palkowitz, A.D. Applications of tartrate ester modified allylic boronates in organic synthesis-An efficient, highly stereoselective synthesis of the C(19)-C(29) segment of rifamycin-S. J. Am. Chem. Soc. 1987, 109, 953-955. [CrossRef]

130. Ziegler, F.E.; Kneisley, A. 3-Methyl-gamma-butyrolactone as a source of 2-methyl-3-hydroxyketones and 2-methyl-1,3-diols-A synthesis of the C19-C27 fragment of rifamycin-S by linear iteration. Tetrahedron Lett. 1987, 28, 1725-1728. [CrossRef] 
131. Ziegler, F.E.; Cain, W.T.; Kneisley, A.; Stirchak, E.P.; Wester, R.T. Applications of the 3-methyl-gamma-butyrolactone strategy to the synthesis of polypropionates-the Prelog-Djerassi lactonic ester, ent-invictolide, and the C19-C27 fragment of rifamycin S. J. Am. Chem. Soc. 1988, 110, 5442-5452. [CrossRef]

132. Tarara, G.; Hoppe, D. Total synthesis of protected D-altro-3,6-dideoxy-3-C-methylhexose and D-galacto-3,6-dideoxy-3-Cmethylhexose-Key intermediates of a rifamycin S synthesis. Synthesis 1989, 2, 89-92. [CrossRef]

133. Born, M.; Tamm, C. Stereoselective Synthesis of the C(19)-to-C(27) Segment of Rifamycin S. Helvetica Chim. Acta 1990, 73, 2242-2250. [CrossRef]

134. Roush, W.R.; Palkowitz, A.D.; Ando, K. Acyclic diastereoselective synthesis using tartrate ester-modified crotylboronates. Double asymmetric reactions with alpha.-methyl chiral aldehydes and synthesis of the $\mathrm{C}(19)-\mathrm{C}(29)$ segment of rifamycin S. J. Am. Chem. Soc. 1990, 112, 6348-6359. [CrossRef]

135. Harada, T.; Kagamihara, Y.; Tanaka, S.; Sakamoto, K.; Oku, A. A highly convergent asymmetric synthesis of the C(19)-C(27) segment of rifamycin S: An application of enantiodifferentiating acetalization with menthone. J. Org. Chem. 1992, 57, 1637-1639. [CrossRef]

136. Lautens, M.; Belter, R.K. The effect of remote oxygens on the ring-opening reactions of oxabicyclic compounds with organolithium reagents. Synthesis of the C21-C27 segment of rifamycin S. Tetrahedron Lett. 1992, 33, 2617-2620. [CrossRef]

137. Miyashita, M.; Yoshihara, K.; Kawamine, K.; Hoshino, M.; Irie, H. Synthetic studies on polypropionate antibiotics based on the stereospecific methylation of gamma,delta-epoxy acrylates by trimethylaluminum-A highly stereoselective construction of the 8 contiguous chiral centers of ansa-chains of rifamycins. Tetrahedron Lett. 1993, 34, 6285-6288. [CrossRef]

138. Harada, T.; Oku, A. Enantiodifferentiating transformation of prochiral polyols by using menthone as chiral template. Synlett 1994, 2, 95-104. [CrossRef]

139. Yadav, J.S.; Rao, C.S.; Chandrasekhar, S.; Rao, A.V.R. Asymmetric synthesis of C-19 to C-27 fragment of rifamycin-S. Tetrahedron Lett. 1995, 36, 7717-7720. [CrossRef]

140. Hanessian, S.; Wang, W.; Gai, Y.; Olivier, E. A General and Stereocontrolled Strategy for the Iterative Assembly of Enantiopure Polypropionate Subunits: Synthesis of the C19-C28 Segment of Rifamycin S from a Single Chiron. J. Am. Chem. Soc. 1997, 119, 10034-10041. [CrossRef]

141. Marshall, J.A.; Palovich, M.R. Synthesis of Stereopentad Subunits of Zincophorin and Rifamycin-S through Use of Chiral Allenyltin Reagents. J. Org. Chem. 1998, 63, 3701-3705. [CrossRef]

142. Turks, M.; Huang, X.; Vogel, P. Expeditious Asymmetric Synthesis of a Stereoheptad Corresponding to the C(19)-C(27)-Ansa Chain of Rifamycins: Formal Total Synthesis of Rifamycin S. Chem. A Eur. J. 2004, 11, 465-476. [CrossRef]

143. Kim, J.W.; Adachi, H.; Shin, Y.K.; Hayakawa, Y.; Seto, H. Apoptolidin, a new apoptosis inducer in transformed cells from Nocardiopsis sp. J. Antibiot. 1997, 50, 628-630. [CrossRef]

144. Hayakawa, Y.; Kim, J.W.; Adachi, H.; Shin-Ya, K.; Fujita, A.K.-I.; Seto, H. Structure of Apoptolidin, a Specific Apoptosis Inducer in Transformed Cells. J. Am. Chem. Soc. 1998, 120, 3524-3525. [CrossRef]

145. Wender, P.A.; Sukopp, M.; Longcore, K. Apoptolidins B and C: Isolation, Structure Determination, and Biological Activity. Org. Lett. 2005, 7, 3025-3028. [CrossRef]

146. Wender, P.A.; Longcore, K.E. Isolation, Structure Determination, and Anti-Cancer Activity of Apoptolidin D. Org. Lett. 2007, 9 , 691-694. [CrossRef]

147. Wender, P.A.; Longcore, K.E. Apoptolidins E and F, New Glycosylated Macrolactones Isolated from Nocardiopsis sp. Org. Lett. 2009, 11, 5474-5477. [CrossRef]

148. Salomon, A.R.; Voehringer, D.W.; Herzenberg, L.A.; Khosla, C. Understanding and exploiting the mechanistic basis for selectivity of polyketide inhibitors of F0F1-ATPase. Proc. Natl. Acad. Sci. USA 2000, 97, 14766-14771. [CrossRef]

149. Benitez-Bribiesca, L. Assessment of apoptosis in tumor growth: Importance in clinical oncology and cancer therapy. In When Cells Die; Lockshin, R.A., Zakeri, Z., Tilly, J.L., Eds.; Wiley-Liss: New York, NK, USA, 1998; pp. 453-492.

150. Salomon, A.R.; Vöhringer, D.W.; Herzenberg, L.A.; Khosla, C. Apoptolidin, a selective cytotoxic agent, is an inhibitor of F0F1-ATPase. Chem. Biol. 2001, 8, 71-80. [CrossRef]

151. Salomon, A.R.; Zhang, Y.; Seto, H.; Khosla, C. Structure-Activity Relationships within a Family of Selectively Cytotoxic Macrolide Natural Products. Org. Lett. 2000, 3, 57-59. [CrossRef]

152. Nicolaou, K.C.; Li, Y.; Fylaktakidou, K.C.; Mitchell, H.J.; Sugita, K. Total Synthesis of Apoptolidin: Part 2. Coupling of Key Building Blocks and Completion of the Synthesis. Angew. Chem. Int. Ed. 2001, 40, 3854-3857. [CrossRef]

153. Nicolaou, K.C.; Fylaktakidou, K.C.; Monenschein, H.; Li, Y.; Weyershausen, B.; Mitchell, H.J.; Wei, H.-X.; Guntupalli, P.; Hepworth, D.; Sugita, K. Total Synthesis of Apoptolidin: Construction of Enantiomerically Pure Fragments. J. Am. Chem. Soc. 2003, 125, 15433-15442. [CrossRef]

154. Wehlan, H.; Dauber, M.; Fernaud, M.-T.M.; Schuppan, J.; Mahrwald, R.; Ziemer, B.; Garcia, M.-E.J.; Koert, U. Total Synthesis of Apoptolidin. Angew. Chem. Int. Ed. 2004, 43, 4597-4601. [CrossRef]

155. Wehlan, H.; Dauber, M.; Fernaud, M.T.M.; Schuppan, J.; Keiper, S.; Mahrwald, R.; Garcia, M.-E.J.; Koert, U. Apoptolidin A: Total Synthesis and Partially Glycosylated Analogues. Chem.-A Eur. J. 2006, 12, 7378-7397. [CrossRef]

156. Wu, B.; Liu, Q.; Sulikowski, G.A. Total Synthesis of Apoptolidinone. Angew. Chem. Int. Ed. 2004, 43, 6673-6675. [CrossRef]

157. Ghidu, V.P.; Wang, J.Q.; Wu, B.; Liu, Q.; Jacobs, A.; Marnett, L.J.; Sulikowski, G.A. Synthesis and Evaluation of the Cytotoxicity of Apoptolidinones A and D. J. Org. Chem. 2008, 73, 4949-4955. [CrossRef] 
158. Crimmins, M.T.; Christie, H.S.; Chaudhary, A.K.; Long, A. Enantioselective Synthesis of Apoptolidinone: Exploiting the Versatility of Thiazolidinethione Chiral Auxiliaries. J. Am. Chem. Soc. 2005, 127, 13810-13812. [CrossRef]

159. Chau, S.T.; Sulikowski, G.A.; Wu, B. Studies on the synthesis of the apoptolidins. In Strategies and Tactics in Organic Synthesis; Harmata, M., Ed.; Elsevier Science Publ. Co. Inc.: San Diego, CA, USA, 2012; Volume 8, pp. 375-394.

160. Craita, C.; Didier, C.; Vogel, P. Short synthesis of the C16-C28polyketide fragment of apoptolidin A aglycone. Chem. Commun. 2007, 23, 2411-2413. [CrossRef] [PubMed]

161. Rubottom, G.M.; Vazquez, M.A.; Pelegrina, D.R. Peracid oxidation of trimethylsilyl enol ethers: A facile $\alpha$-hydroxylation procedure. Tetrahedron Lett. 1974, 15, 4319-4322. [CrossRef]

162. Bonini, C.; Chiummiento, L.; Pullez, M.; Solladie, G.; Colobert, F. Convergent Highly Stereoselective Preparation of the C12-C24 Fragment of Macrolactin A. J. Org. Chem. 2004, 69, 5015-5022. [CrossRef] [PubMed]

163. Hartung, I.V.; Niess, B.; Haustedt, L.O.; Hoffmann, H.M.R. Toward the Total Synthesis of Disorazole A1 and C1: Asymmetric Synthesis of a Masked Southern Segment. Org. Lett. 2002, 4, 3239-3242. [CrossRef]

164. Brown, H.C.; Bhat, K.S.; Randad, R.S. Chiral synthesis via organoboranes. 21. Allylboration and crotylboration of alpha-chiral aldehydes with diisopinocampheylboron as the chiral auxiliary. J. Org. Chem. 1989, 54, 1570-1576. [CrossRef]

165. Kolb, H.C.; VanNieuwenhze, M.; Sharpless, K.B. Catalytic Asymmetric Dihydroxylation. Chem. Rev. 1994, 94, 2483-2547. [CrossRef]

166. Bouchez, L.C.; Vogel, P. Synthesis of the C(1)-C(11) Polyene Fragment of Apoptolidin with a New Sulfur Dioxide-Based Organic Chemistry. Chem. A Eur. J. 2005, 11, 4609-4620. [CrossRef]

167. Ramberg, L.; Bäcklung, B. The reactions of some monohalogen derivatives of diethyl sulfone. Ark. Kemi. Mineral. Geol. 1940, 13A, $1-50$.

168. Chan, T.L.; Fong, S.; Li, Y.; Man, T.O.; Poon, C.D. A new one-flask Ramberg-Bäcklund reaction. J. Chem. Soc. 1994, 15, 1771-1772. [CrossRef]

169. Cao, X.P. Stereoselective synthesis of substituted all-trans-1,3,5,7-octatetraenes by a modified Ramberg-Bäcklund reaction. Tetrahedron 2002, 58, 1301-1307. [CrossRef]

170. Narasaka, K.; Pai, H.C. ChemInform Abstract: STEREOSELECTIVE SYNTHESIS OF MESO (OR ERYTHRO) 1,3-DIOLS FROM $\beta$-HYDROXYKETONES. Chem. Inf. 1981, 12. [CrossRef]

171. Exner, C.J.; Laclef, S.; Poli, F.; Turks, M.; Vogel, P. Total asymmetric syntheses of $\beta$-hydroxy- $\delta$-lactones via Umpolung with sulfur dioxide. J. Org. Chem. 2011, 76, 840-845. [CrossRef]

172. Exner, C.J.; Turks, M.; Fonquerne, F.; Vogel, P. Concise synthesis of complicated polypropionates through one-pot disymmetrical two-directional chain elongation. Chem. Eur. J. 2011, 17, 4246-4253. [CrossRef] [PubMed] 